\title{
POLITIČKI ISLAM (ISLAMIZAM), \\ TERORIZAM I UTJECAJ ISLAMSKIH \\ ZEMALJA U BOSNI I HERCEGOVINI
}

\author{
Bernard Dukić \\ bernard.dukic@gmail.com
}

\section{Sažetak}

$\mathrm{U}$ tradiciji islama kao religije postoje ekspanzivne ideje i metode. Cilj islamistički orijentiranih muslimana u konačnici je živjeti u jednoj državi sa šerijatskim zakonom. Politički islam je krajna posljedica takve ideje, te se u političkom islamu islam instrumentalizira u političke svrhe želeći pokoriti sve nemuslimanske narode i države s kojim su u vječnom sukobu (Dahr el Harb - Kuća Rata). U Bosni i Hercegovini, islamizam je postojao tijekom 20.st., a intezivirao se nakon Drugog svjetskog rata djelovanjem Alije Izetbegovića i njegove grupe. Tijekom rata u $\mathrm{BiH}$ 1992.-1995.g., u toj su zemlji djelovale mnoge terorističke skupine, obavještajne službe islamskih zemalja, a i uspostavljena je i službena Muslimanska/Bošnjačka stranka SDA. Nakon rata, mnogi teroristi su ostali, a skupine koje ostaju prijetnja su vehabijska zajednica, terorističke organizacije (kao Al Qai'da), kao i skupine povezane s Muslimanskim bratstvom.

Ključne riječi: islamizam, šerijat, Alija Izetbegović, terorizam, vehabije, AI-Qai'da 


\title{
Islamizam, islam i islamistički terorizam
}

\author{
Islam
}

Islamizam i islam postoje kao dvije odvojene kategorije i nikako nisu istoznačnice. Islam je religija čiji su vjernici muslimani, dok je islamizam politički oblik islama; točnije rečeno, to je politička ideologija i orijentacija oblikovana unutar složenog islamskog svijeta.1 Bilo bi pogrešno tvrditi da je islam sam po sebi politički pokret; prije svega on jest vjerski i nastao je kao božanska objava proroku Muhamedu. Rođen oko 570.g. u gradu Meki u plodnijem pojasu Arapskog poluotoka, Muhamed je provodio život običnog trgovca do objave i poziva koje je iskusio 610.g. u brdima blizu Meke. Po njegovom uvjerenju, obratio mu se Bog a on je utemeljio vjeru koju je nazvao islam- što znači predanost jedinom Bogu (Allah) i priznavanje Njegove opstojnosti i svemoći.2 Propovijedao je Božju Riječ, Kur'an, malobrojnim sljedbenicima u Meki i svojoj obitelji. Preokret se dogodio kad se je preselio u grad Jesribu (Medina) gdje je zavladao naseljem rastrzanim unutarplemenskim sukobima. Postupno je povećavao broj svojih sljedbenika- muslimana- te ujedinio brojna plemena Arabije i osvojio Meku. U Medini je ustanovio prvu islamsku državu gdje je on bio kalif- u sebi je ujedinio Božjeg poslanika, vojskovođu i vladara.3 To se je odvijalo 622.g., te je sljedećih 10 godina, do svoje smrti, Muhamed ustanovio sve najvažnije odredbe- vjerske i svjetovne- nove vjere boreći se za ujedinjenje arapskih plemena i prevlast u Meki. Sam je vodio rat i bitke protiv Kurejšita, plemena koje je vladalo Mekom. Na kraju su muslimani- oni predani Allahupod vodstvom svog Proroka osvojili Meku, a Muhamed se vratio u Medinu i umro 632.g.4 I već površnom analizom vidljivo je da je i sam Muhamed bio veoma politički aktivan te je uspješno kombinirao novu religiju koju je uspostavio te

1 Bilandžić, Mirko. Sjeme zla: Uvod u studije terorizma. Zagreb: Despot Infinitus, 2014., str. 193, 195

2 Ochsenwald, William. " Muhammad: His Life and Lidership " u: Ochsenwald, William- Fisher, Sydney. The Middle East: A History. New York: McGraw-Hill, 2004., str. 25-26

3 Kulenović, Tarik. Politički islam: Osnovni pojmovi, autori i skupine jednog modernog političkog pokreta. Zagreb: V.B.Z., 2008., str. 26

4 Mantran, Robert. " Muhamed i islam " u: Povijest 5- Kasno Rimsko Carstvo i rani srednji vijek ( ur. Enrico Cravetto). Zagreb: Jutarnji list, 2007., str. 503-508 
političku moć koju je nametnuo, skupa sa svim pravnim i drugim propisima donesenim za nove vjernike. Današnji rezultat Muhamedove vjerske a i političke revolucije je činjenica da je islam druga najzastupljenija religija sa oko milijardu i pol sljedbenika5, a u čak 27 država je službena državna vjera i to u zemljama sjeverne i subsaharske Afrike, Bliskog Istoka te u nekim državama u Aziji.6

O Muhamedovim političkim i osvajačkim potezima se još da i raspravljati7, no politika njegovih nasljednika ne ostavlja mjesta sumnji da su svoj islam kao religiju spojili $s$ osvajanjima i utemeljenjem nove države. Nakon smrti Muhameda 632.g., ujedinjenim Arapskim poluotokom i novom svjetskom silom su upravljali kalifi (ar. Khalifa- nasljednik) od kojih je prvi bio Abu Bakr (632.-634.g.), zatim Umar, Utman te Ali koji su postali poznati kao rašiduni (pravedni kalifi). Umar i Utman su kao vladari osvojili golema područja koja su obuhvaćala Egipat, Siriju, Palestinu te Srednji Istok- u njihovo se vrijeme islamska vjera etablirala a država proširila. Značajan je raskol uslijedio vladavinom četvrtog kalifa Alija (656.-661.g.). Ali je bio jedan od prvih obraćenika na islam, slijedio je Muhameda na njegovu putu i oženio njegovu kćer. Uslijedio je sukob između njega i upravitelja Sirije Muavije u kojem je potonji pobijedio, a Ali je ubijen. Prije svoje smrti Ali je utemeljio shi'at Ali - Alijinu stranku, te su po tome nazvani šijiti- grana muslimana koji štuju Aliju kao sveca osobito povezanog s Bogom i smatraju da Muhamedova obitelj ima pravo voditi islamski svijet. Oni posjeduju i ponešto drukčiju teologiju od većinski orijentiranih muslimana, sunita, no ipak se svi slažu u bitnom.8 Nakon ovog raskola, Muavija je utemeljio dinastiju Umajida i prebacio sjedište svoje države u Damask, a osnivač dinastije Abasida (750.- 1258.g.) u Bagdad - time su islamsko carstvo i islam kao religija postali pokret svjetskih razmjera. U 10.st. muslimani vladaju područjem od Španjolske do Indije.9

5 https://berkleycenter.georgetown.edu/essays/demographics-of-islam Pristup 23.5.2019.

6 https://www.theguardian.com/world/2017/oct/03/more-than-20-percentcountries-have-official-state-religions-pew-survey 23.5.2019.

7 Jedan ga je povjesničar zgodno opisao kao kombinaciju Isusa Krista u smislu vjerskog reformatora i Karla Velikog kao osvajača; Kulenović, Tarik. Politički islam, str. 26

8 Mantran, Robert. " Muhamed i islam ", str. 517-520; Kulenović, Tarik. Politički islam, str. 27-28

9 Kulenović, Tarik. Politički islam, str. 30, 36 
Već je istaknuto kako je islamizam zapravo politički islam; politička ideologija koja koristi islamsku religiju kao bazu svog političkog djelovanja. Korijeni modernog političkog islama se datiraju u 19.st. (uz pojavu vahabizma u 18.st. u današnjoj Saudijskoj Arabiji). Ideološki proto-učitelji islamizma su bili u biti vjerski reformatori koji su se opirali kolonijalizmu zapadnoeuropskih zemalja i smatrali da je religija islama javna stvar, a time i politika. U 19.st. i prvoj polovici 20.st. istaknuli su se vjerski učitelji poput Iranca Jamal Al- Dina AlAfghanija, Egipćanina Muhammeda Abduhua te Sirijca Rašida Rida.10

Ipak, pravi temelj za ono što će postati islamizam je dao Egipćanin Hasan Al-Banna osnovavši organizaciju Muslimanska braća (Društvo muslimanske braće, ar. Ikhwan al Muslimin) 1928.g. u Egiptu, u Isma' iliyyi. Hasan Al-Banna je također htio reformirati svoju državu vraćajući muslimane na pravi put; originalni put proroka Muhameda i prihvaćanje Kur'ana kao vrhovnog zakona u državi. U početku je Muslimansko bratstvo djelovalo preko socijalne pomoći u Egiptu posebno naglašavajući obrazovanje, no kasnije se militariziralo.11 Po njemu muslimani ne trebaju težiti europskim vrijednostima. Bratstvo je postalo uzor za sve islamističke organizacije nastale kasnije12 i po tome je ova organizacija vrlo značajna. Isto se udruženje proširilo na brojne ogranke i slične organizacije po cijelom islamskom svijetu, a njene franšize uglavnom uključuju politiku nenasilja, no ne uvijek. Palestinski Hamas, kojeg SAD drži terorističkom organizacijom, je izrastao iz Bratstva; iz njegovog ogranka je šeik Ahmed Jassin osnovao neprofitnu organizaciju u Izraelu 1978.g. koja je postala Hamas. ${ }^{13}$ Sadašnji emir i vođa AlQaide, dr. Ayman Zawahiri, je također bivši pripadnik egipatskog Muslimanskog bratstva. ${ }^{14}$ lako su započeli kao

10 Kulenović, Tarik. Politički islam, str. 89-96

11 Fisher, Sydney Nettleton. " The Egyptian Republic and Independent Sudan " u : Ochsenwald, William- Fisher, Sydney. The Middle East: A History. New York: McGraw-Hill, 2004., str. 583-584

12 Bilandžić, Mirko. Sjeme zla, str. 192-193; Isti. " Islamske oružane organizacije i islamizam na primjeru Bliskog istoka ", Revija za sociologiju, XXXIX (4), str. 309

13Bilandžić, Mirko. " Islamske oružane organizacije i islamizam na primjeru Bliskog istoka ", str. 319

14 https://www.nytimes.com/2019/04/30/world/middleeast/is-the-muslimbrotherhood-terrorist.html 
organizacija više orijentirana na obrazovanje i karitativnu pomoć, Bratstvo je postalo i radikalni pokret koji želi uspostaviti teokratsku državu. Za regiju zapadnog Balkana i za sigurnost $\mathrm{BiH}$ i Hrvatske treba spomenuti (o čemu će još biti riječi) da je i organizacija Mladi muslimani iz $\mathrm{BiH}$, osnovana 1941.g., izrasla po uzoru na Muslimansko bratstvo iz Egipta i s njima održavala intenzivne kontakte. ${ }^{15}$

U svjetskim okvirima, može se reći kako je islamizam doživio veliki zamah tijekom zadnje četvrtine 20.st. Nakon još jednog poraza Palestinaca i drugih arapskih zemalja od strane Izraela, fokus muslimanskog svijeta se okrenuo na druge države. Možda je presudna 1979. godina kada su započela dva događaja koja će imati dalekosežne posljedice. Prvi je Islamska revolucija u Iranu kojom je na vlast došao ajatolah Ruhollah Homeini, konzervativni šijitski vjerski vođa, zbacivši šaha Rezu Pahlavija s vlasti.16 Masivne demonstracije, štrajkovi i loša ekonomska situacija je prisilila šaha da početkom siječnja 1979.g. napusti zemlju koju je preuzeo spomenuti klerik. U Iranu je tada uspostavljena republika s islamskim predznakom. Iran više nije bio monarhija (nakon dvije i pol tisuće godina), već je postao republika sa nekim teokratskim predznacima i čuvarima novog poretka, koju utjelovljuje Islamska Revolucionarna Garda (eng. IRGC Iranian Revolutionary Guard Corps). ${ }^{17}$ Revolucionarna Garda je vojna, sigurnosna i obavještajna služba koja odgovara izravno ajatolahu i opisuje se kao prava pretorijanska gardaelita koja zapravo djeluje kao država unutar države. Skupa s MOIS-om (Ministry of Intelligence and Security) ${ }^{18}$ formira glavnu obavještajnu snagu u zemlji i inozemstvu, a njene

15 Mlivončić, Ivica. Al Qaida se kalila u Bosni i Hercegovini. Split- Mostar: Naša ognjišta- Tomislavgrad, 2007., str. 30-31

16 Kissinger, Henry. Svjetski poredak. Zagreb: Školska knjiga, 2015., str. 136- 138

17 Fisher, Sydney Nettleton. " The Islamic Republic of Iran, the Collapse of the Soviet Union, and War in Afghanistan " u: Ochsenwald, William- Fisher, Sydney. The Middle East: A History. New York: McGraw-Hill, 2004., str. 514- 516; Kulenović, Tarik. Politički islam, str. 121-123. Nakon što je predsjednik SAD-a Trump proglasio IRGC stranom terorističkom organizacijom, u travnju 2019.postala je i nedostupna službena stranica Revolucionarne garde sepahnews.com; https://www.aljazeera.com/news/2019/04/designates-iran-elite-irgcterrorist-organisation-trump-190408141756166.html

18 MOIS je nastao iz obavještajne službe SAVAMA koju je osnovao ajatolah Homeini 1984., te je zamijenila prijašnju službu SAVAK; još se naziva i https://www.globalsecurity.org/intell/world/iran/vevak.htm 
specijalne snage (Quds) su djelovale tijekom rata u Bosni i Hercegovini. ${ }^{19}$

Drugi vrlo bitan događaj za islamski svijet, sa posljedicama koje su dovele do islamskog terorizma i nastanka Al- Qaide, je bila intervencija Sovjetskog Ssaveza u Afganistan također 1979.g. Sovjeti su, želeći sačuvati marksističku vladavinu u Afganistanu, intervenirali i vojskom ušli u tu zemlju gdje su Afganistanci gerilskim ratovanjem pružili žestok otpor. No, ono što je počelo kao manji sukob je preraslo u internacionalni zanos muslimana koji su odlazili u džihad (sveti rat) kao mudžahedini boreći se protiv nevjernika. Šeik Abdullah Azzam, Palestinac, je zadojen džihadističkom idejom otvorio Makhtab-e-Khidamat Al-Mujahideen tj. Ured za mudžahedinske usluge u pakistanskom Peshawaru, gdje su brojni muslimani iz raznih zemalja (Egipćani, Palestinci, Saudijci, Jemenci itd.) ulazili u Afganistan i postajali "sveti ratnici". ${ }^{20}$ Azzam je bio član spomenutog Muslimanskog bratstva, a Ured je u Peshawaru služio kao središnja baza za propagandu, novačenje i prikupljanje sredstava za borbu protiv Sovjeta. On je i osnovao Al- Qaidu kao " čvrstu bazu " (ar. Al-Qaeda al-Sulbah) u vidu stvaranja temelja za daljne borbe protiv nevjernika. Tijekom 1980-ih, bogati Saudijac Osama bin Laden je pomalo preuzeo Al- Qaidu i pretvorio je u terorističku organizaciju svjetskih razmjera. ${ }^{21}$

Islamizam je pojava koju se može okarakterizirati kao instrumentalizaciju religije; dakle, to je pokret koji je u svojoj biti i politički i religijski budući da smatra da je islam religija, način života i država- po tom konceptu društvo mora biti uređeno po pravilima šerijatskog zakona. ${ }^{22}$ Jedan je znanstvenik definirao islamizam kao "religijsku ideologiju koja sadrži holističku interpretaciju islama čiji je konačni cilj osvajanje svijeta svim sredstvima". ${ }^{23}$ To je ideologija koja je religijski i vremenski regresivna - teži povratku u prošlost (salaf), u vrijeme Muhamedova upravljanja Medinom te vrijeme vladavine rašiduna - prva 4 kalifa. Holistička

19 Wege, Carl Anthony. " Iran's Intelligence Establishment ", The Intelligencer: Journal of U.S. Intelligence Studies, 21 (2), str. 6465

20 Kohlmann, Evan. Al- Qa'idin džihad u Europi: Afganistanskobosanska mreža. Zagreb: Naklada Ljevak, 2005., str. 18- 23

21 Bilandžić, Mirko. Sjeme zla, str. 199- 200.

22 Isto, str. 195

23 Mozaffari, Mehdi. " What is Islamism? History and Definition of a Concept ", Totalitarian Movements and Political Religions, 8 (1), str. 21 
interpretacija označava da islamisti svoju vjeru vide kao din, dunya i dawla - spomenuta religija, način života i država. Ono što islamisti uistinu teže jest osvajanje svijeta koje im je čak i Allah u Kur'anu obećao24, te tako smatraju da im svijet i pripada. 25

\section{Islamstički terorizam}

Terorizam je sam po sebi kompleksan i slojevit pojam. Povijest se modernog terorizma smješta u 19.st. s pojavom anarhističkih akcija, a različiti autori i institucije različito definiraju pojam terorizma. Tako autori NATO Leksikona opisuju terorizam kao "nezakonitu uporabu sile ili nasilja ili prijetnja uporabom iste protiv osoba ili imovine kako bi se zastrašilo ili na nešto prisililo vladu, civilno stanovništvo ili bilo koji dio društva te promaknulo vlastite političke, ideološke ili društvene ciljeve."26 Neki drugi znanstvenici daju više deskriptivno objašnjenje bez čvrste definicije. Dominique Venner smatra kako je terorizam različit od ratnog čina ili običnog političkog nasilja; ono za cilj ima poniziti protivnika a ne ga potpuno poraziti jer mu nije dorastao. Terorizam je izazov slabijeg jačemu želeći posijati strah i nasilnu reakciju jačeg i tako ga defamirati. ${ }^{27} \mathrm{O}$ samom pojmu nema potrebe ovdje iznositi teorijske pretpostavke i razne zaključke, no treba istaknuti kako je terorizam veoma opasan politički, društveni i sigurnosni fenomen suvremenog doba te predstavlja napad na nacionalnu sigurnost neke države i njene stanovnike. ${ }^{28}$ Može se pojednostavniti kazavši kako je terorizam uporaba terora radi ostvarenja političkih ciljeva; on je dualne prirode, sastoji se od nasilja i političkog djelovanja.29 Postoje još neki elementi terorističkih akata; oni započinju kriminalnim djelovanjima, nasiljem ali zapravo imaju drugi cilj u vidu. To je ujedno i psihološka operacija koja želi zadati strah i paniku društvu kojeg napada.30 Islamski terorizam ima

24 Sura $7,128-129$

25 Mozafffari, Mehdi. " What is Islamism?...", str. 22-23

26 NATO Leksikon ( ur. Laković, Aleksandar- Stojan, Kristina ). Zagreb: Topical, 2008., str. 180

27 Venner, Dominique. Povijest terorizma. Zagreb: Alfa, 2005., str. 8-9

28 Bilandžić, Mirko. Sjeme zla, str. 19; ekstenzivno o terorizmu u ovom istom radu.

29 Isto, str. 126

30 Anderson, Sean K.- Sloan, Stephen. Historical Dictionary of Terrorism. Lanham- Toronto- Plymouth: The Scarecrow Press, 2009., lii-liii 
svoj korijen u političkom islamu. Islamizam je, kako je istaknuto, politička ideologija (više njih) koja smatra kako islam nije samo religija nego i politički sustav te da se muslimani trebaju vratiti korijenima svoje vjere.31 Ipak, različite islamske oružane organizacije i terorističke grupe imaju različite ciljeve; neki radikalni islamisti žele rušiti sekularne poretke u svojim državama, kao egipatska Islamska grupa (ar. Al-Gama'at al-Islamiyya), neki žele rušiti nemuslimanske vlasti kao grupe u Čečeniji a neki razmišljaju šire kao Al- Qaida koja teži poraziti SAD i Zapad.32 Zanimanje i pozornost cijelog svijeta islamski je terorizam zadobio u drugoj polovici 20.st. i početkom 21.st., i to događajima koji uključuju arapsko-izraelski sukob (četiri sukoba od 1948.g. do 1973.g.), zatim iransko-irački rat u 1980-ima, prva i druga intifada te posebno udar Al-Qaide i njenog emira Osame bin Ladena 11. rujna 2001.g. na SAD.33 Napadi 11.rujna su bili osobito okrutni i smrtonosni; život je izgubilo oko 3000 ljudi, a SAD i saveznici su pokrenuli " Rat protiv terora " (War on Terror); vojno je napadnut Irak i Afganistan, a islamski terorizam se zapravo razbuktao - broj terorističkih napada se višestruko povećao u islamskim zemljama i preuzeo primat u svijetu.34 Pitanje je također je li taj rat uopće pomogao; neki stručnjaci osporavaju politiku Georga Busha Mlađeg i ističu kako je Al- Qaida dobila točno što je htjela, a to je slika u svijetu SAD-a koji napada i ratuje protiv islamskog svijeta kao novi križari.35 Neke islamističke terorističke organizacije relevantne za ovaj rad su:

Islamska grupa (ar. Gama'at al Islamiya) - egipatska Islamska grupa je islamistička, militantna i teroristička organizacija, najveća u arapskom svijetu osnovana 1973.g., kojoj je primarni cilj rušenje sekularnog poretka u Egiptu. Njen duhovni vođa i utjecajna osoba je bio zloglasni slijepi šeik Omar Abdul Rahman koji je proglasio fatwu za eliminaciju egipatskog predsjednika Anwara Sadata 1980.g., što su Islamska grupa i Islamski džihad i učinili 1981.g. Kasnije je Grupa pokušala i atentat na predsjednika Hosnija Mubaraka. Teroristički akti ove organizacije su brojni, te treba izdvojiti masakr u hramu Luxor u Egiptu 1997.g. kad je ubijeno 58 turista. 1999.g. vodstvo Islamske grupe je donijelo odluku o prekidu nasilnog djelovanja, što je pokušao spriječiti Ayman

31 Bilandžić, Mirko. "Islamske oružane organizacije i islamizam na temelju Bliskog istoka ", str. 310

32 Isto, str. 314

33 Isto, str. 210

$34 \mathrm{https}$ ://ourworldindata.org/terrorism Pristup 2.6.2019.

35 https://ourworldindata.org/terrorism Pristup 2.6.2019. 
Zawahiri, egipatski ideolog Al-Qaide i sadašnji emir te organizacije. Ipak, teroristički napadi su se nastavili, kao onaj 2005.g. u ljetovalištu Sharm al-Sheikhu. ${ }^{36}$ Ova organizacija je poduzela i jedini teroristički napad na tlu Republike Hrvatske, u Rijeci 1995.g.37 Ista je bila veoma aktivna tijekom rata u Bosni i Hercegovini.38

Hamas - akronim arapskog naziva Harakat al Mukawama al Islamiya (Islamski Pokret Otpora) je islamistička fundamentalistička palestinska organizacija čiji je cilj brisanje Države Izrael s lica zemlje i uspostava islamističke države u Palestini. Osnovana 1987.g. od strane šeika Ahmeda Yassina, svoj početak ima u organizaciji Mudžama utemeljenoj 1978.g. od strane istog šeika u Izraelu. Yassin je bio pripadnik utjecajnog Muslimanskog bratstva i Hamas je nastavio održavati veze $s$ tom organizacijom. Ideologija Hamasa je bliska Bratstvu i terorističkoj grupi Islamski džihadobe su sudjelovale u ubojstvu egipatskog predsjednika Anwara Sadata. Hamas je u trajnom ratu s Izraelom, a potporu mu pružaju brojne muslimanske države poput Jordana, Sirije, Libanona, Sudana ali i Irana premda su sunitska grupa.39

Al- Qaida - je globalna, džihadistička, fundamentalistička teroristička organizacija bazirana na salafističkoj ideologiji koja ima za cilj povratak izvornim postulatima islama i uvođenje šerijatskog prava po cijelom svijetu. Salafizam označava pokret koji teži stvaranju idealne, čiste islamske zajednice po uzoru na salafe (prijatelje) Muhameda. Prema nekim procjenama40, oko milijun muslimana salafističkog usmjerenja je spremno za uporabu nasilja. Meta Al-Qaide su zapadne države (SAD, Velika Britanija i druge), zatim muslimanske države koje su saveznici Zapada te druge muslimanske organizacije koje su im prijetnja ili su sekularnog uvjerenja. ${ }^{41}$ Al-Qaida se može još uvijek smatrati ozbiljnom

36 Anderson, Sean K.- Sloan, Stephen. Historical Dictionary of Terrorism, str. 301-303; Bilandžić, Mirko. " Islamske organizacije i islamizam na primjeru Bliskog istoka ", str. 321-323

37 Kohlmann, Evan. Al- Qa'idin džihad u Europi: Afganistanskobosanska mreža, str. 190-191

38 Mlivončić, Ivica. Al Qaida se kalila u Bosni i Hercegovini, str. 211

39 Anderson, Sean K.- Sloan, Stephen. Historical Dictionary of Terrorism, str. 227- 237; Bilandžić, Mirko. " Islamske organizacije i islamizam na primjeru Bliskog istoka ", str. 319

40 Bilandžić, Mirko. Sjeme zla, str. 198

41 Bilandžić, Mirko. Sjeme zla, str. 198; Anderson, Sean K.- Sloan, Stephen. Historical Dictionary of Terrorism, str. 557 
prijetnjom Zapadu, pa time i Bosni i Hercegovini, posredno i susjedu Republici Hrvatskoj i Hrvatima u $\mathrm{BiH}$, iz nekoliko razloga koji se najviše tiču njena konačna cilja i strategije.

Al- Qaida se rodila u ratu u Afganistanu. Već je spomenuto kako je Palestinac iz Jordana, Abdullah Azzam, član Muslimanskog bratstva, osnovao uslužni ured MAK (Maktab al Khidamat) u Peshawaru u Pakistanu za propagandu, prikupljanje sredstava i novačenje svetih ratnika. " Bazu " je preuzeo bogati Saudijac Osama bin Laden 1988.g., a Azzam je potom brzo ubijen. Poznato je kako je američka CIA podupirala mnoge mudžahedinske grupe preko pakistanske službe ISI, iako nisu pronađeni nijedni direktni dokazi između CIA-e i MAK-a. Al- Qaida je primala pomoć i od drugih obavještajnih službi i država; tako su iranski MOIS i Hezbollah sudjelovao u treningu boraca Al-Qaide u Sudanu, kampovima Hezbollaha u Libanonu i Iranu.42

Ciljevi Al-Qaide su definirani još tijekom devedesetih godina prošlog stoljeća te su strategijski opisani u dokumentu Plan/Strategija 2020. Al- Qaida se nada, i radi na tome, da do 2020.g. dostigne svoj glavni cilj; uspostavu globalnog islamističkog kalifata preko sedam faza koje jedna drugu nadopunjuju.43 Ciljevi srednjeg vremenskog dometa su radikalizacija islamskog društva diljem svijeta, borba protiv sekularnih muslimanskih država, uništenje Izraela i SAD-a. Praktični ciljevi obuhvaćaju i posjedovanje i razvijanje oružja za masovno uništenje te daljni razvitak u upotrebi eksploziva i zapadnjačke tehnologije koju koriste za napade.44 Ono što je posebno zabrinjavajuće po Republiku Hrvatsku i Bosnu i Hercegovinu je činjenica da Al- Qaida ima posebne planove na Balkanu. Naime, nakon što je u ratu 1990-ih sudjelovala na strani Bošnjaka/Muslimana u $\mathrm{BiH}$ i razvila svoju terorističku mrežu, vodstvo Al-Qaide je poslije rata počelo iskorištavati domaće muslimane kao svoje teroriste poglavito zbog toga što su postali tzv. bijela Al- Qaida; izgledom mladi Europljani plave kose i svijetle boje očiju. Zbog toga in je dosta teže identificirati i sprječiti u njihovim naumima. Vođa organizacije, dr. Ayman Zawahiri, je 2013.g. predstavio i plan " Balkan

42 Anderson, Sean K.- Sloan, Stephen. Historical Dictionary of Terrorism, str. 557, 558, 564; Bilandžić, Mirko. " Al- Qaida: nastanak, struktura i strategija ", Polemos 11 (1), str. 34-36

43 Bilandžić, Mirko. " Al- Qaida: nastanak, struktura i strategija ", str. 41

44 Anderson, Sean K.- Sloan, Stephen. Historical Dictionary of Terrorism, str. 559 
2020. ", gdje potvrđuje Balkanski poluotok kao jedan od centara islamskog terorizma i njihovog djelovanja. ${ }^{45}$

Organizacijski, Al- Qaida je hijerarhijski ustrojena; njome upravlja emir i vijeće savjetnika. Ima vojno i političko krilo te tijela zadužena za vojna i politička pitanja, planiranje operacija, obavještajna te sigurnosna djelovanja, tijela za logistiku i financiranje. ${ }^{46} \mathrm{Na}$ vrhu hijerarhije je emir, danas Ayman Zawahiri. On ima svog zamjenika te tajnika. U zapovijednom vijeću postoje odjeli za političku djelatnost, vjerska pitanja, administraciju i financiranje te poseban odjel za medijsku djelatnost i propagandu. Pitanje je djeluje li ova organizacija kao strogo hijerarhijska prema svojim mrežama i filijalama diljem svijeta, ili služi kao krovna organizacija koja umrežuje sve te organizacije. ${ }^{47}$ Ono što treba zaključiti u vezi $\mathrm{BiH}$ i Republike Hrvatske je činjenica da je Al- Qaida teroristička organizacija koja se u ratu ubacila u $\mathrm{BiH}$ i razvila svoju mrežu te je nastojala, i vjerovatno će dalje nastojati, iskoristiti to područje za svoje strateške ciljeve - islamizaciju Balkana i prodor prema Europi i SAD-u. ${ }^{48}$

\section{Islamizam i islamistički terorizam u Bosni i Hercegovini}

\section{Pojava islamizma u $\mathrm{BiH}$ do raspada Jugoslavije i rata}

U socijalističkoj Jugoslaviji SR Bosna i Hercegovina je bila jedna od 6 republika, a Muslimani su 1971.g. postali jedna od priznatih nacija, iako je njihova religioznost bila dosta površna i više sekularne prirode. ${ }^{49}$ Sigurnosne i obavještajne službe u SFRJ, SDB/SDS (zvana i UDB-a) uz vanjsku obavještajnu službu SID (Služba za istraživanje i dokumentaciju pri Sekretarijatu inostranih poslova) kao i vojne službe (Vojna obavještajna služba pri Il.upravi Generalštaba JNA te UBUprava Bezbednosti JNA u sastavu SSNO-a), su bile zadužene za zaštitu komunističkog poretka i vlasti SKJ te

45 Gibas- Krzak, Danuta. " Terrorism in the Balkans. Genesis- typesprognoses ", Internal Security Review 19/18, str. 326

46 Bilandžić, Mirko. " Al- Qaida; nastanak, struktura i strategija ", str. 37

47 Gunaratna, Rohan- Oreg, Aviv. " Al Qaeda's Organizational Structure and its Evolution ", Studies in Conflict and Terrorism 33 (12), str. 1045, 1054-1056

48 Kohlmann, Evan. Al- Qa'idin džihad u Europi: Afganistanskobosanska mreža, str. 37

49 Gibas- Krzak, Danuta. " Terrorism in the Balkans. Genesis- typesprognoses ", str. 323 
predsjednika Tita u zemlji od svih neprijatelja; raznih vrsta nacionalizma, vjerskih pokreta, vanjskih i unutarnjih protivnika. ${ }^{50}$ Tako su i SDB BiH i SID sudjelovale u otkrivanju islamističkih prijetnji iznutra i van države koji su prijetili tadašnjoj vlasti. Tijekom 1960-ih i pogotovo 1970-ih politički islam je diljem svijeta ojačao; 1969.g. osnovana je i međunarodna politička organizacija islamskih zemalja, Organization of Islamic Cooperation (OIC). Na trećoj konferenciji ove organizacije 1981.g., fokus se je prebacio na muslimanske manjine diljem svijeta, a na sastanku u Kairu 1982.g. odlučeno je da se jača politički islam u Jugoslaviji kao put za jačanje muslimanskih zajednica diljem Balkana. ${ }^{51}$

I sama komunistička Jugoslavija je sudjelovala u stvaranju terorističke prijetnje; naime, u Obavještajno-bezbednosnom školskom centru (OBŠC), nazvanim tako 1975.g. sa središtem u Pančevu, održavana je obuka budućih obavještajaca, sigurnosnih stručnjaka, vojnih policajaca ali i terorista, pripadnika terorističkih grupa - među svima njima bilo je dosta Arapa, kao i brata Sadama Huseina. ${ }^{52}$ Između 1960.g. i 1986.g. kroz taj je centar obuku prošlo preko 800 stranih državljana iz 10 zemalja, među njima i oni iz PLO-a (eng. Palestine Liberation Organisation). Sve je to bilo vrlo unosno budući da je SFRJ, tj. njene tvrtke, zarađivala godišnje oko 713 milijuna dolara prodavajući oružje raznim stranim skupinama i državama. ${ }^{53}$

Za razumijevanje pojave političkog islama, dolazak stranih mudžahedina u BiH tijekom rata 1992.-1995.g., kao i pojave islamskog terorizma nakon rata, teško je dovoljno naglasiti koliko je važna uloga Alije Izetbegovića. ${ }^{54}$ Rođen u Bosanskom Šamcu 1925.g., 1946.g. jugoslavenske su ga vlasti uhitile i osudile na tri godne zatvora budući da je bio pripadnik organizacije Mladi muslimani koja je nastala po uzoru na Muslimansko bratstvo Hasana al-Banne. Još kao

50 Žunec, Ozren.- Domišljanović, Darko. Obavještajno-sigurnosne službe Republike Hrvatske. Zagreb: Jesenski i Turk, 2000., str. 33-41; Akrap, Gordan. " Mač i štit u rukama Partije- represivni sustav u funkciji oblikovanja javnog znanja ", National Security and the Future 4 (11), 2011., str. 205 i dalje

51 Lučić, Ivo. " Bosna and Herzegovina and Terrorism ", National Security and the Future 3-4 (2), 2001., str. 121- 122

52 Starešina, Višnja. Hrvati pod KOS-ovim krilom. Zagreb: Avid Media- Hrvatsko katoličko sveučilište, 2017., str. 209- 210; Lučić, Ivo. " Bosna and Herzegovina and Terrorism ", str. 114 53 Lučić, Ivo. " Bosna and Herzegovina and Terrorism ", str. 115 54 http://www.enciklopedija.hr/natuknica.aspx?id=28280 
mladić, dakle, postao je zadojen islamističkom ideologijom te je te svoje ideje predočio u tekst dokumenta Islamske deklaracije koju je napisao 1969.g., a objavio 1970.g. U njemu iznosi svoj program islamizacije bošnjačkih Muslimana i muslimanskih naroda. U ožujku 1983.g., djelatnici SDS-a Sekretarijata unutarnjih poslova $\mathrm{SR} \mathrm{BiH}$ su upali u stan Alije Izetbegovića te ga uhitili zbog širenja islamskog fundamentalizma; s njime su i neke druge osobe uhićene i osuđene, a Alija je dobio 14 godina zatvora iako je izašao krajem 1988.g. ${ }^{55}$ Optužnica je imala svoj temelj na spomenutom tekstu Islamska deklaracija u kojoj Izetbegović donosi svoje viđenje ustrojstva islamskog društva. U njemu tvrdi kako onaj narod koji je prihvatio islam može živjeti i boriti se samo za taj ideal. Nije puno držao do nacionalizama smatrajući islam nadnacionalnim, djelotvornijim pokretom te je na izricanju presude kazao kako se je uvijek smatrao borcem za islam. ${ }^{56}$

Postojalo je tijekom 1980-ih još nekoliko slučajeva islamističkog fundamentalizma u $\mathrm{SR} \mathrm{BiH}$ te su još neki ljudi osuđeni. Ipak, ključna je bila uloga Alije Izetbegovića. Nakon promjene vlasti, potvrđeni su kontakti između Mladih muslimana, skupine kojoj je Izetbegović pripadao, i Muslimanskog bratstva, organizacije koja je, kako je rečeno, veoma utjecala na razvoj islamističkih organizacija. ${ }^{57}$

Nakon što je izišao iz zatvora 1988.g., Izetbegović je osnovao prvu muslimansku stranku; SDA- Stranka demokratske akcije 26.svibnja 1990.g. u Sarajevu. Održao je i govor na utemeljiteljskoj skupštini SDA koji je započeo islamskim pozdravom iz Kur' ana; Bismillahir-rahmanir-rahim (U ime Allaha, Svemilosnog, Samilosnog), pozdravom koji stoji na početku svake sure (osim jedne) u Kur'anu. ${ }^{58} \mathrm{U}$ lipnju 1991.g., Savjet za nacionalnu obranu SDA je osnovao oružanu formaciju Patriotsku ligu čija je zadaća bila braniti cjelovitost $\mathrm{BiH}$, ali i zaštita muslimanskog naroda. Glavni utemeljitelj i operativac Patriotske lige, koja će poslije izrasti u Armiju BiH, je bio bivši oficir JNA Sefer Halilović koji je iskoristio svoja vojna i obavještajna znanja u formiranju jedne

55 Tuđman, Miroslav. Druga strana Rubikona: Politička strategija Alije Izetbegovića. Zagreb: Hrvatska sveučilišna naklada, 2017., str. 13-15; Lučić, Ivo. " Bosna and Herzegovina and Terrorism ", str. 122

56 Lučić, Ivica. Uzroci rata: Bosna i Hercegovina od 1980. do 1992.godine. Zagreb: Despot Infinitus, 2013., str. 136- 138

57 Isto, str. 140

58 Tuđman, Miroslav. Druga strana Rubikona: Politička strategija Alije Izetbegovića, str. 26-27 
takve strukture. Činjenica je da je Patriotska liga bila zapravo stranačka vojska SDA.59 Vrijedi spomenuti i to da je prije prelaska na stranu Bošnjaka/Muslimana, Sefer Halilović bio dugogodišnji suradnik KOS-a, vrbovan još 1975.g. kao potporučnik JNA, te je uhodio i izvještavao za vrijeme višestranačkih izbora u Hrvatskoj pripreme HDZ-a i formiranje Hrvatske Vojske. ${ }^{60}$

Alija Izetbegović je kao vođa SDA i predstavnik Muslimana u $\mathrm{BiH}$ počeo, nakon pobjede na izborima, provoditi ono što je kao mlad pisao u Islamskoj deklaraciji. Nakon raspada SFRJ i proglašenja nezavisnosti Bosne i Hercegovine, mnoge islamske zemlje su ju počele priznavati (Turska, Libija, Iran) i počele joj pomagati na razne načine. Takva potpora islamskih zemalja je samo potvrdilo Izetbegoviću ono u što je vjerovao, a to je ummet; težnja i nastojanje za ujedinjenjem svih muslimana u jednu zajednicu. ${ }^{61}$ Alija Izetbegović je svoje islamističke ideje, povezane još od mladosti sa Muslimanskim bratstvom preko organizacije Mladi muslimani, provodio kao predsjednik $\mathrm{BiH}$ i član predsjedništva kroz cijelo desetljeće (1990.-2000.g.). Preko njegovog saveznika Harisa Silajdžića i sina Bakira Izetbegovića, danas bošnjačkog člana Predsjedništva, njegove ideje dalje žive. ${ }^{62}$ Vrijedna je spomena i činjenica da su i druge osobe u SFRJ bile uhićene i osuđene zbog islamskog fundamentalizma i muslimanskog nacionalizma, a postojala je i muslimanska politička emigracija. ${ }^{63}$

Što se tiče ovog odlomka, može se zaključiti kako je klica islamizma, političkog islama, i islamističkog terorizma koji je niknuo u ratu u $\mathrm{BiH}$ 1992.-95.g. te se nastavio i poslije rata, nastala dosta ranije i to preko grupe Mladi muslimani koja se inspirirala organizacijom Muslimanskog bratstvo. Ključnu je ulogu tu imao Alija Izetbegović, član te organizacije, kao i autor političkog programa Islamska deklaracija kojom vidi islam kao spoj duhovnog i materijalnog, spoj političkog i vjerskog. Takva razmišljanja su dovela do islamističke politike i dolaska mudžahedina, "svetih ratnika" a u biti islamističkih

59 Isto, str. 125, 127

60 Starešina, Višna. Hrvati pod KOS-ovim krilom, str. 29

61 Tuđman, Miroslav. Druga strana Rubikona: Politička strategija Alije Izetbegovića, str. 385

62 Lebl, Leslie. Islamism and Security in Bosnia-Herzegovina. Carlisle, PA: Strategic Studies Institute and U.S. Army War College Press, 2014., str. 6- 7

63 Lučić, Ivica. Uzroci rata: Bosna i Hercegovina od 1980. do 1992.godine, str. 135-140; 160 
terorista iz raznih zemalja. S njima su došle i razne obavještajne službe te terorističke organizacije.

\section{Uloga islamističkih terorističkih organizacija i mudžahedina u ratu u $\mathrm{BiH}$}

Pojava stranih muslimanskih ratnika, mudžahedina, i islamističkih terorističkih organizacija u ratu u $\mathrm{BiH}$ 1992.-95.g. se ne može promatrati bez da se dovede u kontekst već spomenutog buđenja islamizma u muslimanskom svijetu. Istaknuto je kako su dva najvažnija događaja bila 1979.g.; Islamska revolucija u Iranu ajatolaha Homeinija te upad SSSR-a u Afganistanu i posljedični nastanak baze stranih ratnika, mudžahedina, koji su se borili na strani svoje muslimanske braće. Rečeno je i kako je Organizacija islamske suradnje (OIC- Organisation of Islamic Cooperation) prebacila 1982.g. svoj fokus, na konferenciji u Kairu, na muslimanske manjine na Balkanu, $u$ prvom redu na Jugoslaviju.64 Prvi mudžahedini, " sveti ratnici ", su došli u BiH u veljači 1992.g., sa ciljem da pomognu u borbi da islam postane društveni i politički poredak i tako pomognu svojoj braći po vjeri. Čini se da su iranski mudžahedini i pripadnici šiijtskog Hezbollaha iz Libanona bili među prvima koji su dospjeli u Bosnu te su zbog svog vojnog iskustva sudjelovali u obuci vojnika, vojnih policajaca i obavještajaca u Armiji BiH kao i u kampu Pogorelici kraj Fojnice.65 Jasno je da je jedan takav međunarodni odjek za džihad u Bosni bio i posljedica djelovanja muslimanskih političara, kao što su stavovi Alije Izetbegovića. To je i priznao reis Islamske zajednice $\mathrm{BiH}$ Mustafa Cerić 1999.g., rekavši kako su pozvali mudžahedine u Bosnu.66

Prvi islamistički borci koji su dospjeli u džihad u BiH su bili iskusni arapsko-afganistanski ratnici, prekaljeni u protusovjetskom ratu u Afganistanu. Jedan je od njih bio Abdelrahamn al- Dosari, zvan i Abu Abdel Aziz " Barbaros ", veteran afganistanskog rata i sudionik džihadističkog djelovanja u Africi, Kašmiru i Filipinima. On je 1992.g. došao sa 4 iskusna borca u Bosnu i Hercegovinu te je malo kasnije vodstvo pristiglih mudžahedina njega imenovalo za prvog emira (vrhovnog zapovjednika) islamističkih Arapa pristiglih u

64 Lučić, Ivo. " Bosna and Herzegovina and Terrorism ", str. 122

65 Tuđman, Miroslav. Druga strana Rubikona: Politička strategija Alije Izetbegovića, str. 386

66 Isto, str. 387 
Bosnu i Hercegovinu.67 Tako je Abu Aziz organizirao dolazak stranih islamskih boraca, pretežno već ratnih veterana, dok je prijam, dolazak i raspored mudžahedina u Bosni i Hercegovini 1992.g. odrađivao general Fikret Muslimović Fićo. Fikret Muslimović je bio dugogodišnji oficir KOS-a JNA, pukovnik i kontraobavještajac te se istaknuo kao čovjek koji se borio protiv islamizma; odjednom okrenuvši kaput, postao je veza mudžahedina, Armije BiH i Alije Izetbegovića.68

Strani islamistički borci, mudžahedini, su dolazili kao strani državljani kao aktivisti dobrotvornih ustanova, novinari ili preko diplomatsko-obavještajnih veza. Osim što su bili ratnici koji su sudjelovali u ratu u BiH, bili su i nositelji obavještajne djelatnosti za razne države, pretežno iz one iz koje bi stizali. U prvim borbama su sudjelovali mudžahedini iz raznih zemalja $\mathrm{i}$ islamističkih terorističkih grupa, kao što su Hezbollah, Hamas, Islamska grupa (Al- Gama'at al- Islamiya), Islamski džihad iz Jemena, GIA (Groupe Islamique Armee) iz Alžira.69

$\mathrm{U}$ rat u BiH se uključila i Al Qaida. Njeni ciljevi, osim pomaganja svojoj muslimanskoj braći, su zapravo bili drukčiji; cilj je bio stvoriti sigurnu bazu za djelovanje u Europi i time što više svojim terorizmom zahvatiti Zapadnu Europu i na kraju, SAD. S geopolitičkog gledišta, Bosna i Hercegovina je zemlja duboko u Europi i predstavlja sjajnu osnovu za islamske terorističke organizacije da što dublje prodru na Zapad. Abu Abdel Aziz je potvrdio kako mu je sam Osama bin Laden rekao da vidi Bosnu prvenstveno kao polaznu točku na napad na SAD.70

Vrhovni vjerski i politički ideolog svih stranih muslimanskih boraca u $\mathrm{BiH}$ je za vrijeme rata bio ratoborni egipatski šeik imena Anwar Shabaan. Taj je egipatski klerik, obrazovan čovjek (s završena dva fakulteta), bio veteran rata u Afganistanu, no 1991.g. se je preselio u Italiju i u Milanu osnovao Islamski kulturni centar čiji je bio vođa. Koristio je taj centar za novačenje mladih Arapa i muslimana diljem Europe te ih je na stotine slao u terorističke organizacije, među njima i Al Qaidu. Centar je postao žarište terorističkih grupa kao što

67 Kohlmann, Evan. Al Qa' idin džihad u Europi: Afganistanskobosanska mreža, str. 32-35

68 Mlivončić, Ivica. Al Qaida se kalila u Bosni i Hercegovini, str. 120 69 Isti, str. 118, 121, 139

70 Kohlmann, Evan. Al Qa' idin džihad u Europi: Afganistanskobosanska mreža, str. 36; Mlivončić, Ivica. Al Qaida se kalila u Bosni i Hercegovini, str. 109 
su Islamska grupa i GIA. Shabaan je tri godine bio politički, djelom i financijski, pokrovitelj islamističkih aktivnosti u $\mathrm{BiH}$. Utemeljivši tvrtku-paravan u Italiji, financirao je obuku i oružje za mudžahedine u Bosni i Hercegovini. 1992.g. Shabaan i Abu Aziz " Barbaros " su utemeljili logore za džihad (obuku) u srednjoj Bosni, u mjestima Mehurići i Zenici. Također je Anwar bio i glavni ideolog odreda " El Mudžahid ".71

Neslavno je završio kada je smrtno stradao 1995., u konvoju koji se od Zenice kretao prema frontu u Zavidovićima. Na drugom kontrolnom punktu HVO-a na ulazu u Žepče, vozila su zaustavljena te je izbio sukob. Vojnici HVO-a su smrtno ranili Shabaana i još četvoricu njegovih suputnika. Kod Shabaana i ostalih su nađene identifikacijske kartice zaposlenih osoba Agencije za pomoć trećem svijetu (eng. TWRA - Third World Relief Agency), humanitarne organizacije koja je služila kao paravan Al Qai' idi i Saudijcima za slanje novca i oružja islamistima u Bosni i Hercegovini.72

Odred "Mudžahid" je bio sastavljen od stranih boraca mudžahedina koji su postali službeni dio Armije $\mathrm{BiH}, \mathrm{u}$ sastavu 3.korpusa. Povjerljivom odlukom koju je donio zapovjednik Štaba Vrhovne komande Armije BiH, general Rasim Delić, 13.kolovoza 1993.g. je osnovao ovu postrojbu koja se odlikovala hrabrošću ali još više okrutnošću u ratu. Simbol joj je bio crna zastava s otvorenim Kur' anom te dva kalašnjikova, a imala je svoje obavještajno-logističke predstavnike u Zagrebu i Splitu.73 Njihov emir, zapovjednik odreda, Abu el Ma' ali je 1995.g. izjavio kako su se došli boriti za širenje islama u svijetu, a tada je procijenjeno da u njegovoj postrojbi ima oko 2000 boraca.74 Broj islamističkih " svetih ratnika " nije nikad točno utvrđen. Spominju se brojke do 2000 do 3000 ljudi za odred " El Mudžahid ", zatim informacija el Ma' alija kako u Bosni ima 5000-6000 pravih mudžahedina, kao i procjena Tihomira Blaškića o 3000-4000 stranih

71 Tuđman, Miroslav. Druga strana Rubikona: Politička strategija Alije Izetbegovića, str. 394; Kohlmann, Evan. Al Qa' idin džihad u Europi: Afganistansko- bosanska mreža, str. 38-41, 43; Mlivončić, Ivica. Al Qaida se kalila u Bosni i Hercegovini, str. 140

72 Kohlmann, Evan. Al Qa' idin džihad u Europi: Afganistanskobosanska mreža, str. 215-216

73 Tuđman, Miroslav. Druga strana Rubikona: Politička strategija Alije Izetbegovića, str. 394; Mlivončić, Ivica. Al Qaida se kalila u Bosni i Hercegovini, str. 151- 152

74 Lučić, Ivo. " Bosna and Herzegovina and Terrorism ", str. 127 
islamističkih boraca.75 Za zaključak bi se mogla uzeti nekakva srednja ocjena ovih brojki i reći kako je bilo minimalno 3 do 5 tisuća stranih islamističkih boraca.

Put kojim je stizala pomoć muslimana u Bosni i Hercegovini u vidu ljudstva, logistike i oružja je vrlo zanimljiv. Najvećim dijelom su bile uključene Saudijska Arabija i pogotovo Islamska Republika Iran, s kojom su Alija i Bakir Izetbegović uspostavili posebne veze.76 Preko tzv. " hrvatske rute " stizali su mudžahedini i oružje u $\mathrm{BiH}$ skrivajući se iza različitih islamskih organizacija te ustanova. Oružje je većinom kupovao Iran, svojim ili financijama Saudijske Arabije, zatim je bilo prebačeno iranskim zrakoplovima u Zagreb. Nakon toga je tako pristigao materijal stizao na Brač, gdje bi konvojima i helikopterima išao za Bosnu.77 Sjedinjene Američke Države su znale za ove akcije, a bila je uključena i obavještajna služba Pentagona (Department of Defense).78 Zanimljivo je da je grad Split bio važno logističko središte za Armiju BiH i mudžahedine. U Splitu je bio veliki prihvatni centar za muslimanske izbjeglice iz $\mathrm{BiH}$, a iz Zagreba Hasan Čengić je upućivao islamističke teroriste u Split gdje su dočekani od strane splitske islamske zajednice. Neki od najpoznatijih terorista su bili Al Afgani, pripadnik Al Qai'de, koji je toliko dugo operativno djelovao u Splitu da je dobio nadimak Abu Dujam. Kroz Split je prošlo i oko 150 pripadnika Al Qai'de, a 1993. tu je bio i Muhamed Zawahiri, brat sadašnjeg emira Aymana Zawahirija.79

Al Qai'da je bila jedna od terorističkih islamističkih organizacija koje su djelovale u $\mathrm{BiH}$ tijekom rata, no njena aktivnost se nastavila i nakon 1995.g. Tu prvenstveno treba uzeti u obzir temeljni cilj i polaznu točku s kojom je Osama bin Laden uopće krenuo u Bosnu i Hercegovinu, a to je njen geopolitički položaj. Al Qai'da je zamijetila kako je Bosna i Hercegovina u sjajnom geografskom položaju za njene potrebe; muslimani u Bosni i Hercegovini predstavljaju mogućnost da se dođe do zemlje na krajnem zapadu Balkana i vrlo blizu srca Europe. Na taj način AI Qai'da želi doći svojim

75 Tuđman, Miroslav. Druga strana Rubikona: Politička strategija Alije Izetbegovića, str. 392; Mlivončić, Ivica. Al Qaida se kalila u Bosni i Hercegovini, str. 127

76 Lebl, Leslie. Islamism and Security in Bosnia-Herzegovina, str. 16-20

77 Mlivončić, Ivica. Al Qaida se kalila u Bosni i Hercegovini, str. 247 78 Vanjska obavještajna služba Pentagona tj. Ministarstva obrane SAD-a je DIA ( Defense Intelligence Agency ); http://www.dia.mil/ 79 Mlivončić, Ivica. Al Qaida se kalila u Bosni i Hercegovini, str. 249 
terorističkim metodama do Beča, Pariza i dalje do SAD-a, što je zapravo glavni cilj ove organizacije. Bin Laden je želio stvoriti osnovu, bazu, u Europi za djelovanje protiv Amerikanaca.80 Također, spomenut je plan ove organizacije koju je iznio njen emir Ayman Zawahiri 2013.g., koja stavlja Balkanski poluotok (plan se i zove Balkan 2020.) u središte strategije Al Qai'de kojom se želi na tom području pojačati islamistički terorizam i iskoristiti tzv.bijelu Al Qai'du- njihove teroriste i suradnike podrijetlom Europljane a time $\mathrm{i}$ teže prepoznatljive od strane struktura vlasti. 81

Da je Al Qai'da imala ozbiljne i dugotrajne namjere u Bosni i Hercegovini te vidjela tu zemlju kao tranzitnu točku prema daljnoj islamizaciji Europe i širenju terorizma, pokazuje i činjenica, osim spomenutog plana Balkan 2020., da je i tokom rata u $\mathrm{BiH}$ a dijelom i poslije ova organizacija slala svoje visoke časnike i organizatore da djeluju sukladno svojim ciljevima. Tako je u proljeće 1992.g. Anwar Shabaan došao u srednju Bosnu iz Milana da bi se u jesen iste godine sastao sa izaslanikom bin Ladena Jamalom al-Fadlom i zapovjednicima Arapa u BiH, šeikom Abu Abdelom Azizom (" Barbaros ") i Abu Zubairom al- Madanijem, visokim časnikom Al Qai'de koji je bio i bin Ladenov rođak.82 Dogovoreno je da će Al Qai'da utemeljiti logore za obuku u BiH, sklopiti odnose s agencijama za pomoć u BiH te zasnovati tvrtke kao paravan da financiraju djelatnosti Al Qai'de.83 Nakon rata, Al Qai'da je itekako ostala u BiH. Neki njihovi članovi su se infiltrirali i vjenčali se domaćim djevojkama dobivši tako državljanstvo. Godine 2001. 5 mudžahedina je uhićeno u BiH, a George Robertson, glavni tajnik NATO-a, je izjavio kako barem jedan od njih ima potvrđene veze s Al Qai'dom. Također, iste je godine objavljen članak u talijanskim medijima o uhićenju i izručenju u Egipat Hasana Masuda El Sharifa Saada, jednog od ključnih bin Ladenovih ljudi na Balkanu i uopće Europi. Isti

80 Kohlmann, Evan. Al Qa' idin džihad u Europi: Afganistanskobosanska mreža, str. 37; Mlivončić, Ivica. Al Qaida se kalila u Bosni i Hercegovini, str. 307

81 Gibas- Krzak, Danuta. "Terrorism in the Balkans. Genesis- typesprognoses ", str. 326

82 Kohlmann, Evan. Al Qa' idin džihad u Europi: Afganistanskobosanska mreža, str. 35; Mlivončić, Ivica. Al Qaida se kalila u Bosni i Hercegovini, str. 314

83 Kohlmann, Evan. Al Qa' idin džihad u Europi: Afganistanskobosanska mreža, str. 36 
je bio jedan od organizatora terorističkog napada u Rijeci u $\mathrm{RH}$ 1995.g.84

Dalo bi se nabrojati još nekoliko ozbiljnih incidenata iz $\mathrm{BiH}$ povezanih s AI Qai'dom. Tako je u Hrvatskoj 2005.g. otkrivena urota kojom se željelo izvršiti teroristički napad na pogreb pape Ivana Pavla II., a koja je započela u islamističkom uporištu Gornjoj Maoči u Bosni i Hercegovini. Godine 2006. grupa Bošnjaka i Makedonaca povezanih s Al Qai'dom je uhićena u sjevernoj Italiji nakon što su prokrijumčarili oko 1800 komada oružja u Italiju iz Istanbula. Ured visokog predstavnika (Office of the High Representative) međunarodne zajednice u Sarajevu je 2008.g. otkrio dokaze kako je istaknuti bošnjački političar Hasan Čengić dijelom financirao napade 11.rujna. 85

Al Qai'di je Bosna i Hercegovina bila važna iz više razloga. Najvažniji je, dakako, spomenuti geopolitički položaj. Tijekom rata u Bosni i Hercegovini, cijelo vrijeme su operativci Al Qai'de stvarali svoje mreže suradnika i podatke dobivene svojim obavještajnim radom i onih od mudžahedina su prvo dostavljali svom vođi i centru svoje organizacije, a ne Armiji $\mathrm{BiH}$ kojoj su bili formalno podređeni. Nakon rata, dvije činjenice su postale veoma bitne i međusobno se isprepletale. Oko 900 mudžahedina je dobili bosanskohercegovačko državljanstvo, na stotine su ostale u BiH. Time je stvorena baza s kojom je Al Qai'da mogla dalje djelovati u $\mathrm{BiH}$, a pogotovo prema Zapadu jer je glavni cilj bio da se ti pripadnici Al Qai'de prebace na tlo Europske Unije, u Veliku Britaniju i na kraju, u SAD. Posebno je opasno što ti islamisti više ne izgledaju kao gorštački borci iz Afganistana; oni su se europeizirali, školovali, potpuno se uklopili u sustav Zapada i time postali " spavači " - ljudi koji su vjerni Al Qai'di, ali in se vrlo teško može identificirati. Ni na koji način oni na sebe ne privlače pozornost pričama, stavovima već rade nadzor, istražuju i špijuniraju te in takav pristup čini izrazito opasnim. 86

84 Lučić, Ivo. " Bosna and Herzegovina and Terrorism ", str. 136-138 85 Lebl, Leslie. Islamism and Security in Bosnia-Herzegovina, str. 910

86 Višnar, Fran. " Pogovor " u: Al Qa' idin džihad u Europi: Afganistansko- bosanska mreža, str. 290, 293-298 


\section{Uloga nevladinih dobrotvornih društava u ratu u BiH $\mathbf{i}$ financiranju terorističkih organizacija}

Model financiranja kakav je djelomično uspostavila Al Qai'da tijekom rata u Afganistanu prebačen je u Bosnu i Hercegovinu. Bogate nevladine humanitarne organizacije iz Arapskog zaljeva su nabavljale oružje, smještaj i putovnice članovima Al Qai'de i drugim islamistima u Afganistanu skrivajući se pod krinkom pomoći izbjeglicama. Izvješće američke Središnje obavještajne agencije (CIA) iz 1996.g. govori kako je otprilike trećina svih islamskih nevladinih organizacija na Balkanu pomagala djelovanju islamističkog terorizma, financirajući i podupirući organizacije kao Islamska grupa (Gama' at al-Islamiyya), palestinski Hamas i Hezbollah. Tako su islamske nevladine dobrotvorne organizacije prevozile oružje i streljivo umjesto lijekova i druge robe. 87

Podloga po kojoj su islamske humanitarne organizacije radile pomažući radikalne islamiste i teroriste $u \mathrm{BiH}$ je nastala po modelu izgrađenom u Afganistanu. Humanitarci su većinom financirali i potpomagali na razne načine talibane kao i mrežu Al Qai'de, a sve je to preneseno u Bosnu i Hercegovinu tijekom rata. Tako te humanitarne službe postaju logistička središta preko kojih terorističke organizacije ali i neke islamske zemlje naoružavaju, financiraju i vojno obučavaju mudžahedine $\mathrm{i}$ teroriste. 88 Treba spomenuti one najbitnije među koje spadaju:

TWRA (Third World Relief Agency)- Agencija za pomoć Trećem svijetu, kako se službeno zove, možda je bila i najaktivnija i najopasnija "humanitarna" islamska organizacija koja je krijumčarila oružje i pomagala islamiste u BiH. Osnovana je 1987.g. u Beču od strane Mohammeda Fatiha el Hassanina, s uredima u Moskvi, Sarajevu, Budimpešti i Istambulu. Temeljni cilj je bio širenje islama u zemljama bivšeg socijalističkog bloka, a u ratu u $\mathrm{BiH}$ se istaknula krijumčarenjem oružja i financiranjem džihadista i islamističkih grupa. Ovu agenciju je osnovao i vodio spomenuti Fatih el Hassanein, rodom Sudanac rođenom blizu Kartuma. Fatih je izgradio $i$ iskoristio veze $s$ važnim bošnjačkim političarima, Alijom Izetbegovićem, Omerom

87 Kohlmann, Evan. Al Qa' idin džihad u Europi: Afganistanskobosanska mreža, str. 55-57

88 Mlivončić, Ivica. Al Qaida se kalila u Bosni i Hercegovini, str. 221; Kohlmann, Evan. Al Qa' idin džihad u Europi: Afganistanskobosanska mreža, str. 55 
Behmenom i drugim. Sudan je tada služio kao jedna od glavnih tranzitnih točaka gdje je išao ilegalni prijevoz oružja za Armiju BiH. Njegov brat, Sukarno, je bio član Nacionalnog islamskog fronta u Sudanu (NIF - National Islamic Front) te je prikupljao novac i za Muslimansko bratstvo te uspostavio veze sa bin Ladenom.89 Zanimljivo je da je sve to bio i osobni kružok povjerljivih Izetbegovićevih islamista; tako su Hasan Čengić i Omer Behmen osuđeni s Alijom 1983.g. od strane jugoslavenskih vlasti zbog islamizma. Kasnije je Hasan Čengić bio u odboru direktora TWRA kada je krijumčarila novac za oružje u $\mathrm{BiH}$, dobrim dijelom novcem Iranaca. S druge strane, aktivan u SDA i kao ambasador u Iranu je djelovao Omer Behman.90

Izvješće CIA-e iz 1995.g. potvrđuje vezu radikalnih islamista i nevladinih udruga, gdje se posebno ističe uloga TWRA. Također, govori se i o povezanosti sudanskog veleposlanstva u Zagrebu koje je preuzeo diplomat iz NIF-a 1994.g., te preusmjerio aktivnosti Agencije za naoružavanje i logističku podršku bošnjačkoj vojsci.91 Također treba spomenuti kako je TWRA doista bila globalna i internacionalna; tako je jedan američki musliman svjedočio kako je u SAD švercao novac dobiven od TWRA kojim se financirala vojna obuka arapskih mudžahedina u SAD-u, a koji su trebali biti upućeni u Bosni i Hercegovini. Ipak, ovoj organizaciji je došao kraj kada je austrijska antiteroristička policijska jedinica upala u njihov ured u Beču. Nađeni su dokumenti koji potvrđuju kako je organizacija barem polovicu od 350 milijuna prikupljenih dolara potrošila na financiranje naoružavanja Armije $\mathrm{BiH} \mathrm{i}$ džihadista u BiH. Fatih Hassanein je primio odlikovanje 1996.g. od Izetbegovića za svoj " humanitarni " rad, a uspio je i preko Turske pobjeći u Sudan.92

BIF (Benevolence International Foundation) - Međunarodna zaklada dobre volje, kako se službeno zvala, je bila još jedna islamska deklarativno humanitarna organizacija, a ustvari paravan raznih skupina za financiranje svjetskog džihada.

89 Kohlmann, Evan. Al Qa' idin džihad u Europi: Afganistanskobosanska mreža, str. 69-71; Mlivončić, Ivica. Al Qaida se kalila u Bosni i Hercegovini, str. 221

90 Lebl, Leslie. Islamism and Security in Bosnia-Herzegovina, str. 23

91 Central Intelligence Agency ( 1995 ). Intelligence Report. DCl Counterterrorist

Center.

Preuzeto

S: https://www.cia.gov/library/readingroom/docs/1995-11-22A.pdf

92 Kohlmann, Evan. Al Qa' idin džihad u Europi: Afganistanskobosanska mreža, str. 69-71; Mlivončić, Ivica. Al Qaida se kalila u Bosni i Hercegovini, str. 235- 236 
Glavnu ulogu u ovoj organizaciji je igrala Saudijska Arabija, čiji je državljanin bio i osnivač BIF-a, Adel Batterjee (1987.g.). Zapravo, BIF je odraz spoja političkog i religijskog radikalizma i interesa Saudijske Arabije, budući da su naftom bogati Saudijci od 1970-ih financirali ustanove koje su se borile za "islamsku stvar" diljem svijeta.93 BIF je osnovan 1992.g. i registriran u Illinoisu, SAD, kao neprofitna humanitarna organizacija koja je imala svoje urede u Pakistanu, Bosni, Čečeniji i Kini. Vrlo brzo je čelništvo BIF-a preuzeo Sirijac Enaam Arnaout (albanskog podrijetla), osoba vrlo bliska Osami bin Ladenu. Prethodnik BIF-a je bio Islamski odbor dobre volje (ar. Lajnar al-Birr al-Islamiah) osnovan 1987.g., i to sa svrhom financiranja džihadista u Afganistanu.94

Enaam Arnaout je kao direktor BIF-a u Zagrebu 1992.g. osnovao ured, zatim u Zenici pa u Sarajevu. U Bosni i Hercegovini osniva centre za vjersku i vojnu poduku u Tešnju i pokraj Zenice, a instruktore je davalo zloglasno Muslimansko bratstvo. Arnaout se je vrlo brzo povezao sa čelnim ljudima SDA i njihove obavještajne službe, AID-a (Agencija za istraživanje i dokumentaciju). Posebno dobar odnos je imao sa Nedžadom Ugljenom (poslije šefom te službe i ubijenom 1996.g. u čudnim okolnostima). Nakon zabrane BIF-a, nova organizacija, Bosanska idealna futura, je nastavila operirati na istim načelima a njen direktor je postao jedan pripadnik AID-a, Munib Zahiragić, istaknuti pripadnik radikalnog islama i čovjek koji je zaštitio osumnjičene mudžahedine za ubojstvo doministra MUP-a, Hrvata Joze Leutara, 1999.g.95

BIF je označen kao paravan za Al- Qai'du od službenih američkih vlasti, a njihov direktor Arnaout je 2003.g. počeo služiti desetogodišnju kaznu za financiranje terorizma.96 Godinu dana ranije, policija $\mathrm{BiH}$ je obavila premetačine $\mathrm{u}$ uredima BIF-a, među njima i glavni ured u Sarajevu. Nađeno je vatreno oružje, vojni priručnici, materijali za izradu lažnih putovnica i, ono najbitnije, korespondencija između Osame bin Ladena i vodstva BIF-a, pogotovo Enaama Arnaouta. Tako je zaključeno kao je BIF od 1990-ih korišten od AlQai'de i bin Ladena za prenošenje novca na bankovne račune

93 Mlivončić, Ivica. Al Qaida se kalila u Bosni i Hercegovini, str. 227 94

https://www.un.org/securitycouncil/sanctions/1267/aq sanctions list/ summaries/entity/benevolence-international-foundation

95 Mlivončić, Ivica. AI Qaida se kalila u Bosni i Hercegovini, str. 229232

96 https://www.nytimes.com/2006/02/18/us/national-briefing-midwestillinois-new-sentence-for-charity-director.html 
te zatim financiranje terorista pod krinkom humanitarne organizacije. 97

IIRO (eng. International Islamic Relief Organisation, ar. Hay'at al- Igatha al-Islamiya al-Alamiyya)- Međunarodna islamska humanitarna organizacija, u BiH je postala poznata i pod iskrivljenim nazivom Igasa ili Igasse. Utemeljena 1978.g. sa sjedištem u Jeddahu u Saudijskoj Arabiji, služila je kao financijsko krilo velike Islamske svjetske lige (MWL - Muslim World League). Bila je prva muslimanska "humanitarna" organizacija u $\mathrm{BiH}$, a zapravo je služila kao kanal kojim su išli novac, ljudstvo i oružje na Balkan u borbi za "islamsku stvar". Među ubijenim mudžahedinima nađene su identifikacijske kartice ove organizacije. IIRO je kao ogranak svjetske organizacije operativno djelovao u mnogim područjima i povezivao " svete ratnike ". Tako je indijska obavještajna služba izvjestila kako je IIRO u Pakistanu financirao logor za obuku mudžahedina koji su poslije išli na bojišta u Bosni i Hercegovini, ali i Čečeniji i Kašmiru. " Igassa " je najviše radila na logistici, financiranju oružja i streljiva za islamističke teroriste u cijeloj regiji. Imala je svoje ispostave Zagrebu, Splitu, Sarajevu, Zenici i Beču. Jedan od važnijih individua je bio i čelnik MWL-a u pakistanskom Peshawaru98, islamist Wael Hamza Jaladain, prijatelj i saveznik Osame bin Ladena. Sjedinjene Države su njega imenovale kao čovjeka koji je najviše pomagao bin Ladenu da seli novac i ljude na Balkan.99

\section{Pojava terorističkih akata i prijetnji nakon rata}

U ljeto 1997.g. počinje krvavi niz terorističkih napada preostalih islamističkih boraca, mudžahedina, na Hrvate u Srednjoj Bosni, prvo u travničkom području s time da se kasnije proširilo sve do Mostara. $U$ tom je gradu u rujnu iste godine eksplodirala autobomba, a istragom i bošnjačke i hrvatske policije utvrđeno je da su počinitelji tog zločina pripadnici jedinice " El Mudžahedin " koji su prebacili nekoliko kilograma TNT-a, protutenkovskih mina i ostalog eksploziva

97 Kohlmann, Evan. Al Qa' idin džihad u Europi: Afganistanskobosanska mreža, str. 60-61

98 11.8.1988. u ovom pakistanskom gradu sastala se grupa ljudi koja će iznjedriti terorističku Al-Qai'du; https://www.internationalaffairs.org.au/australianoutlook/manyhappy-returns-of-al-qaeda/

99 Kohlmann, Evan. Al Qa' idin džihad u Europi: Afganistansko- bosanska mreža, str. 64-67; Mlivončić, Ivica. Al Qaida se kalila u Bosni $i$ Hercegovini, str. 226-227 
iz Zenice u Mostar. Te se je godine dogodilo 35 terorističkih akata, a žrtve su preko $90 \%$ bili Hrvati. Sljedeće godine, broj terorističkih napada se popeo na 132, a opet su većinu žrtava činili Hrvati. U mjesecu travnju 1997.g., otkriven je eksploziv ispod mosta nad Miljackom na putu gdje je trebao prolaziti papa Ivan Pavao II., u svom posjetu BiH.100

U spomenutom napadu u Mostaru autobombom, teško je ozljeđeno troje a lakše oko 40 ljudi, s tim da je oštećen velik broj stanova i auta. Bošnjački političari, pogotovo Haris Silajdžić, su često optuživali Hrvate da su sami krivi za taj napad, iako je istraga pokazala da su počinitelji Ahmed Zuhair i Ali Ahmed Ali Hamad. U Travniku su 1998.g. ubijena dvojica hrvatskih policajaca, prvo Perica Bilić a zatim Ante Valjan. U istom gradu sljedeće godine, podmetnuta je bomba pod automobil Hrvata policajca Vlade Stoljana. Policijski očevid je neprofesionalno napravljen, kao i u nekim drugim slučajevima. Vrhunac ovih terorističkih pohoda bivših islamističkih ratnika je bio atentat na Jozu Leutara, zamjenika ministra Ministarstva Unutarnjih Poslova Federacije $\mathrm{BiH}$, čovjeka koji je stalno upozoravao na traljave istrage ovih zločina i sramotne presude. Ujutro 16.ožujka 1999.g., u Sarajevu je eksplodirala bomba podmetnuta pod auto spomenutog zamjenika ministra, pri čemu su u autu još dvojica Hrvata bili ozljeđeni, a Jozo Leutar je preminuo. Nakon tog čina terorizma, odmah se je pokrenula politička mašinerija bošnjačkih dužnosnika, koja je, skupa sa sudskim vlastima, inzistirala da su Leutara ubili Hrvati kriminalci. To izvrtanje teza je čak završilo sa podizanjem optužnice protiv šestorice Hrvata za taj zločin. Obrana je donosila dokaze kako su počinitelji bili isti oni islamisti koji su minirali most na Miljacki za vrijeme papina posjeta.101

Što se tiče prijetnji u vrlo bliskoj prošlosti i danas, treba istaknuti da se islamistička opasnost može ugrubo podijeliti u tri kategorije; to su islamisti vezani uz globalno utjecajno Muslimansko Bratstvo, zatim teroristi koji mogu biti domaći, povezani s Al Qai'dom, kao i vehabije koje je u BiH donijela i nastavlja financirati Saudijska Arabija. Budući da je o svemu manje - više bilo riječi u ovom radu, treba samo još spomenuti da je uz Muslimansko Bratstvo posebice povezan Mustafa

100 Lučić, Ivo. " Bosna and Herzegovina and Terrorism ", str. 129-132; Mlivončić, Ivica. Al Qaida se kalila u Bosni i Hercegovini, str. 191192

101 Isto, str. 130- 135; Isto, str. 194- 197 
Cerić, bivši veliki muftija Sarajeva, kao i Bakir Izetbegović baštineći ideje svoga oca Alije.102

Među incidentima povezanih sa islamizmom $\mathrm{u} \mathrm{BiH}$, treba istaknuti kako je tada 23-godišnji radikalni islamist Mevludin Jašarević, srbijanski građanin iz pretežno muslimanskog Novog Pazara, napao kalašnjikovom Veleposlanstvo SAD-a u Sarajevu 2011.g., ranivši pritom jednog policajca. Direktor OSA-e (Obavještajno-sigurnosne agencije) Almir Džuvo je tada priopćio javnosti kako je Jašarević posjećivao zajednicu radikalnih vehabija u sjevernom dijelu Bosni i Hercegovine.103

Nedavno je (u prosincu 2019.g.) deportirana grupa od 25 državljana BiH iz kampova u Siriji, od kojih su sedmorica bili borci zloglasne Islamske Države (ISIL). Ti su ljudi dovedeni pred sud i sudit će im se za terorizam. Računa se da je bilo oko 260 državljana BiH u kampovima u Siriji.104

Zaključno, treba istaknuti kako je prisutnost islamističkog terorizma itekako živa u Bosni i Hercegovini, a islamizam kao politička ideologija pothranjuje ovu nasilnu borbu za "islamsku stvar". Uzroci i grupe su višestruki, složeni i treba ih razlikovati. $S$ jedne strane postoje ostatci mudžahedina iz rata iz 1990-ih uklopljeni u Bošnjake, zatim individualce teroriste (takozvani vukovi-samotnjaci), nakon toga organizirane terorističke grupe poput Al Qai'de i vehabije. Vehabije se mogu promatrati i kao most između terorističkih grupa i neke organizirane sekte unutar islama, budući da to jest priznata sekta ali sadrži u svojim redovima i teroriste. S druge strane, postoji i državni islamizam vladajuće bošnjačke stranke SDA, zatim utjecaj Muslimanskog Bratstva i značajan utjecaj drugih islamskih država, prvenstveno Irana, Saudijske Arabije i Turske.

\section{Utjecaj muslimanskih država u BiH}

\section{Iranska veza}

Najjači utjecaj u raznim područjima funkcioniranja $\mathrm{BiH}$ i danas ima Islamska Republika Iran, kao što ga je imala i tijekom rata

102 Leslie, Lebl. Islamism and Security in Bosnia-Herzegovina, str. 5- 12

103 https://www.reuters.com/article/us-bosnia-usa-embassy/gunmanattacks-u-s-embassy-in-bosnia-idUSTRE79R66F20111028

104 https://www.euronews.com/2019/12/19/islamic-state-fighters-andtheir-families-return-to-bosnia 
1992.-1995.g. Prisutnost Irana u BiH je složeno pitanje, budući da je Iran međunarodno priznata država te održava diplomatske, gospodarske i druge veze s $\mathrm{BiH}$, no tijekom rata a i kasnije državna politika Irana je išla ka poticanju razvijanja islamizma, a time i terorističkih grupa. Iran za sve to ima svoje osobne interese, a $\mathrm{BiH}$ je prilika za širenje utjecaja Islamske Republike na Balkan i Europu. Tu treba uzeti u obzir i promotriti političko-obavještajni sustav i tradiciju djelovanja iranskih obavještajnih službi. Taj sustav se temelji na čvrsto centraliziranom modelu korištenja relevantnih podataka od strane iranskog predsjednika, vrhovnog vjerskog vođeajatolaha i ostalih donositelja odluka. (Među njima treba istaknuti veoma moćno i utjecno Vijeće čuvara (perz. Šuraye Negahban). To političko tijelo se sastoji od 12 članova koji imaju određene izvršnu i legislativnu moć. Sastavljeno od šestorice pravnika i šestorice teologa, Vijeće ima pravo preispitivati parlamentarne odluke, interpretirati ustav te odobriti izbor predsjednika i članova parlamenta).105 Model se sastoji od civilnih i vojnih obavještajnih i sigurnosnih službi Vojne tajne službe kopnene vojske, zrakoplovstva i mornarice se bave obavještajnim i protuobavještajnim djelovanjem u inozemstvu i zemlji, i to prikupljanjem, obradom analizom i prosudbom informacija. Kako to često biva, vojni atašei ugrađeni u diplomatska predstavništva također rade za te službe.106 Iranski stožer za tajne operacije (eng. Joint Committee for Special Operations), osnovan od vođe islamske revolucije ajatolaha Khomeinija 1989.g., jest civilno obavještajno i sigurnosno tijelo koje prikuplja informacije o visoko razvijenoj vojnoj tehnologiji u inozemstvu i o djelovanju Iranaca van zemlje. Tijekom rata u $\mathrm{BiH}$, i ovo tijelo je bilo prisutno povezujući se $s$ bošnjačkom Agencijom za istraživanje i dokumentaciju te političkim dužnosnicima želeći saznati više o tehnologiji mirovnih snaga; sve skupa bilo in je između 100 i 200.107 Glavna obavještajna služba Irana je MOIS (Ministry Of Intelligence and Security), zvana i VEVAK (Vezarat-e Ettela'at va Amniat-e Keshvar), krovna agencija od 1984.g., koju je također organizirao ajatolah Khomeini. Osim nadziranja domaćeg stanja i opozicije, VEVAK se infiltrira u diplomatska i gospodarska predstavništva u inozemstvu, u banke, među studente, razne stručnjake kao i u Iran Air,

$105 \mathrm{http}: / /$ www.iranicaonline.org/articles/guardian-council

106 Vidušić, Emil. Vodič kroz tajne službe. Split: Naklada Bošković, 2004., str. 87-88; o atašeima ubačenim u diplomatsku službu vidjeti: Vukadinović, Radovan. Politika i diplomacija. Zagreb: Otvoreno Sveučilište, 1984. 
nacionalnu zrakoplovnu kompaniju. Služba odgovara izravno ajatolahu te se osim prikupljanja, analize i obrade informacija bavi i vođenjem operacija iz iranskih veleposlanstava, konzulata i islamskih centara $\mathrm{u}$ inozemstvu.108 Paralelno $\mathrm{s}$ ovim službama, poseban status ima već spomenuta Islamska Revolucionarna Garda IRGC i njihova obavještajna komponenta Obavještajna uprava Revolucionarne Garde (eng. Intelligence Organisation of Revolutionary Guards Corps). Specijalne snage Quds unutar Revolucionarne Garde su također zadužene za skupljanje obavještajnih podataka, kao i za operacije u inozemstvu.109 Što se tiče Irana, islamistički terorizam, obavještajno i tajno djelovanje je sve povezano u jednu cjelinu- drugim riječima radi se o državno sponzoriranom terorizmu po čemu je Iran (a pogotovo Revolucionarna Garda) poprilično poznat (američki State Department je označio Iran kao državu koja podupire terorizam još 1984.); financirao je i sponzorirao razne islamističke skupine, među kojima se posebno ističe potpora libanonskom Hezbollahu.110

Iran ima svoje interese i cijelu obavještajno-terorističku mrežu po cijelom Balkanskom poluotoku, koristeći i pripadnike Hezbollaha za svoje operacije dajući im putovnice. U njihovim očima, Balkan je dobra logistička platforma za regrutiranje i financiranje terorističkih aktivnosti, a geopolitički predstavlja most prema Srednjoj i Zapadnoj Europi. Jedna od zemalja gdje iranske obavještajne službe (skupa s diplomatskom) imaju svoje ispostave je Bugarska (i to čak tri - Sofija, Plovdiv i Varna). Treba spomenuti kako je i Mevlid Jašarević, čovjek koji je izvršio teroristički čin prema veleposlanstvu SAD-a u Sarajevu, imao veze sa radikalima u Gornjoj Maoči i sa iranskim obavještajcima i diplomatima koji su sami pohodili taj vehabijski centar.111

Za ovu temu, a i dugoročno za stabilnost Republike Hrvatske, $\mathrm{BiH}$ i Balkanskog poluotoka, bitno je istaknuti također kako je Iran sustavno podržavao, financirao i potpomagao islamske teroriste u Bosni i Hercegovini tijekom i nakon rata, i to

108 https://www.globalsecurity.org/intell/world/iran/vevak.htm ; Vidušić, Emil. Vodič kroz tajne službe. Split: Naklada Bošković, 2004., str. 8990

109 Wege, Carl Anthony. " Iran's Intelligence Establishment ", str. 66 110 https://2009-2017.state.gov/j/ct/rls/crt/2014/239410.htm

111 Avramov, Kiril. " Under the Radar: Iran's Stealth Presence on the Balkans ", The Globe Post 2018; https://theglobepost.com/2018/12/10/iran-stealth-presence-balkans/ 
većinom preko klana Izetbegović - prvo Alije a zatim (i danas) preko njegovog sina Bakira, vođe SDA i bošnjačke politike.

Iranske službe MOIS (zvana i VEVAK) specijalne snage Quds Iranske Revolucionarne Garde su itekako prisutne i aktivne na prostoru cijelog Balkana, i to, jasno, s namjerom širenja iranskog utjecaja. Te aktivnosti su olakšane zbog činjenice da postoje zemlje kao $\mathrm{BiH} u$ koju su već obavještajno, financijski i diplomatski penetrirali, a s druge strane mnogo zemalja na Balkanu imaju problema sa provođenjem zakona što olakšava provođenje zamišljenih operacija. Osim u Bosni i Hercegovini, Iranci imaju centre u Bugarskoj, a djeluju i na Kosovu.112 Balkanski poluotok je na značajnom geopolitičkom području zbog blizine Središnjoj i Zapadnoj Europi kao i Bliskom Istoku i Kavkazu. Zbog toga Islamska Republika Iran vidi $\mathrm{BiH}$ u koju je već prodrla zahvaljujući vezama iz rata 1992.-1995.g., kao područje iz kojeg će širiti svoj interes prema Europi i dalje.113 VEVAK operira svugdje gdje Iran ima svoj interes, a među njima su Bliski Istok, Srednja Azija, Afrika, Europa, Južna Amerika. Što se tiče Europe, jedno američko izvješće ističe kako su zemlje u kojima Iranci obavještajno djeluju Austrija,

Azerbejdžan, Gruzija, Francuska, Velika Britanija, Njemačka, Turska i Hrvatska, kao i da pružaju financijsku, materijalnu i tehničku pomoć islamskim radikalima diljem svijeta.114 Budući da je jedan od najvažnijih centara iranskih službi Beč115, može se zaključiti kako su Balkan i BiH jedna čvrsta uporišna točka ali i tranzitno područje za širenje iranskog utjecaja i islamskog terorizma prema Središnjoj i Zapadnoj Europi. Taj put vodi i preko Republike Hrvatske.

Ideološki i realpolitički, suradnja SDA Alije Izetbegovića i Irana je bila realnost koja se i ostvarila. Izetbegovićeva Islamska deklaracija koju je napisao u mladosti ima slične ideološko-vjerske osnove kao Islamska revolucija u Iranu 1979.g.; za ajatolaha Homeinija i za Aliju Izetbegovića islam je više od vjere, islam je i društveno-politički poredak te u tome nije važna nacija već ta vjera. Ta činjenica, kombinirana sa iranskim prodiranjem prema Zapadu i njihovoj objektivnoj moći, dovelo je do toga da je Iran imao važnu ulogu u

112 https://www.jpost.com/International/Report-warns-of-Hezbollah-Iranthreats-in-Balkans-309596

113 Hide, Enri. " Islamic Extremism in the Balkans as a Geopolitical Instrument ", Mediterranean Journal of Social Sciences 5 (6), 2014., str. 378

$114 \mathrm{https}: / /$ fas.org/irp/world/iran/mois-loc.pdf

115 https://fas.org/irp/world/iran/mois-loc.pdf 
diplomatskom, financijskom i vojnom pogledu glede pomoći Bošnjaka i naoružavanju i obuke Armije BiH. U svibnju 1991. Alija Izetbegović i njegovi suradnici posjećuju Iran. Godinu poslije u Bosnu i Hercegovinu preko Hrvatske pristižu mnogi " sveti ratnici ", među njima i teroristi iz Hezbollaha - šijtske organizacije koju Iran naoružava, obučava i podupire. Tijekom rata 1992.-1995.g., Iran je poslao u BiH i vojnike, instruktore i obavještajace svoje elitne Revolucionarne Garde (IRGC), s time da su isti sudjelovali u borbama u Armiji BiH, a par stotina njihovih obavještajaca, kao i obavještajaca VEVAK-a u obuci vojnika Armije BiH.116 Kako je običaj iranske obavještajne službe, koriste se diplomatskokonzularnim predstavništvima kao $\mathrm{i}$ islamskim centrima $\mathrm{i}$ humanitarnim organizacijama za svoj obavještajni i teroristički rad.117 Tako je bilo i u Bosni i Hercegovini, s tim da je islamske humanitarne organizacije kontrolirao i koordinirao u svrhu Irana njihov diplomatski predstavnik u Zagrebu, Mohamed Dževad Azajes.118 Iranski vojnici u BiH su najvećim dijelom djelovali kao instruktori i savjetnici. Skupa s financijskom i logističkom pomoći koju je Islamska Republika davala Bošnjacima, treba još istaknuti i par stotinjak Bošnjaka obučavanih u Iranu koji su, uz vojnu i obavještajnu obuku, prolazili $i$ onu ideološko-religijsku. Što se tiče financijskologističke podrške, prvo je 1994.g. ministar vanjskih poslova Irana Ali Akbar Velayati utemeljio iransko veleposlanstvo u Sarajevu koje je vodio iskusni obavještajac Mohamed Taherian. Ministar Velayati je ponudio Izetbegovićevoj vladi prodaju oružja putem Hrvatske, što se dijelom i odvijalo; tako je iste godine iranski Boeing 747 kroz Hrvatsku prokrijumčario 60 tona naoružanja Bošnjacima- sve uz znanje i odobrenje SAD-a.119 Uz to, treba spomenuti i kako je Teheran obučavao neke Bošnjake borbi i terorizmu; ljude koji su kasnije postali pripadnici specijalne postrojbe Armije BiH zvani Ševe, kojima je zapovijedao jedan od pripadnika bošnjačke tajne službe AID-a, Nedžad Ugljen. Put ih je vodio od Splita preko Frankfurta do Teherana, gdje su tri mjeseca bili obučavani u uporabi oružanih napada na vozilima i eksploziva. 120

116 Mlivončić, Ivica. Al Qaida se kalila u Bosni i Hercegovini, str. 288290

117 https://www.globalsecurity.org/intell/world/iran/vevak.htm 118 Mlivončić, Ivica. AI Qaida se kalila u Bosni i Hercegovini, str. 291

119 https://www.academia.edu/21163179/Iran in the Balkans ; Mlivončić, Ivica. Al Qaida se kalila u Bosni i Hercegovini, str. 289-290

120 https://www.academia.edu/21163179/Iran in the Balkans 
Veliki je skandal izbio godinu nakon rata, 2.veljače 1996.g. Tog su dana jedinice NATO-a IFOR (Impletentation Force) otkrile kako su Iranci vodili obuku u obavještajnom, vojnom i terorističkom centru skupa s Bošnjacima u Pogorelici, mjestu blizu Fojnice. Tu su iranski vojni i civilni obavještajci i instruktori obučavali Bošnjake za osiguravanje i izvedbu komunikacija, sabotaži, pravljenju eksploziva, atentatima, crnoj propagandi itd. Nađene su veće količine streljiva i oružja, minskih, eksplozivnih i kamuflažnih sredstava kao i laboratorij. Službena vlada u Sarajevu je, na čelu sa Alijem Izetbegovićem i Bakirom Alispahićem, tada ministrom unutrašnjih poslova (MUP), tvrdila kako je to bio legitimni antiteroristički kamp. Taj "antiteroristički" kamp je pak vodio već spomenuti Nedžad Ugljen, zapovjednik zloglasne specijalne postrojbe Ševe. Američki State Department nije povjerovao $u$ ta objašnjenja te su zahtijevali i ishodili ostavku Bakira Alispahića i Hasana Čengića, glavnog logističara Armije BiH i vezista s Iranom.121

Ono što je zabrinjavajuće je da Iran nikako nije odustao od svoje ispostave za prodor dalje u Središnju i Zapadnu Europu. Godine 2012.istraživačke novine su otkrile kako je gotovo 200 iranskih "poslovnih ljudi" dobilo vize za dolazak u BiH. Daljnje istraživanje je pokazalo da je riječ dijelom o agentima VEVAK-a iz njihove bečke centrale, a drugi dio od obavještajaca snaga Quds iz Islamske Revolucionarne Garde (IRGC). Dvije godine kasnije je visoko pozicionirani obavještajac VEVAK-a stacioniran u Beču dva puta posjetio Bosnu i Hercegovinu. Godinu prije, 2013., političkodiplomatski skandal je izbio u $\mathrm{BiH}$. Ministar sigurnosti, Fahrudin Radončić, je zatražio izbacivanje dvojice iranskih diplomata. Dvojica diplomata, Hamzeh Dolabi Ahmad i Jadidi Sohrab, drugi i treći tajnik iranskog veleposlanstva $u$ Sarajevu, su u biti vrh VEVAK-a i koordinirali njihove aktivnosti. Ta su dvojica, skupa s kulturnim atašeom, viđeni kako nekoliko puta ulaze u diplomatskom vozilu u selo Gornja Maoča. To je naselje itekako poznato budući da je sjedište vehabijske122 zajednice, čiji je jedan vođa Nusret Imamović

121 https://www.balkanspost.com/article/583/potential-terrorism-balkanspart-5-us-government-accusations-pogorelica-case https://www.academia.edu/21163179/Iran in the Balkans Mlivončić, Ivica. Al Qaida se kalila u Bosni i Hercegovini, str. 299301

122 Vehabizam je radikalna, puritanska forma sunitskog islama koja nastoji izbaciti sve strane $i$ druge utjecaje $u$ islamu te se vratiti na postavke islama kakvog je provodio Prorok Muhamed u 7.st. Ime im dolazi od vođe Muhameda bin Abd al Wahhaba, učenjaka iz 18.st. Poglavito su 
bio povezan s islamističkom grupom Al-Nusra,123 a drugi, Bilal Bosnić, je bio član zloglasne Islamske Države (ISIL).124

Za zaključiti je da Islamska Republika Iran ima itekako interesa nastaviti održavati svoj utjecaj i još ga više jačati u Bosni i Hercegovini, pogotovo dok Bošnjake vodi Bakir Izetbegović s čijim su ocem Iranci uspostavili poseban odnos. Iran ima strateške interese za prodor preko Bosne i Hercegovine u Središnju i Zapadnu Europu, a također i u financiranju islamističkih i terorističkih organizacija u Bosni i Hercegovini - sve u svrhu ostvarivanja sve većeg svog utjecaja na Balkanu i šire.

\section{Ostale islamske države}

Saudijska Arabija;o djelatnosti kraljevine Saudijske Arabije, veoma bogate zemlje pod vlašću autokratske dinastije Saud, već je bilo govora. Treba samo ponovno istaknuti kako je Saudijska Arabija prednjačila u davanju financijske i logističke podrške mudžahedinima u BiH tijekom rata te da je uložila veoma visoka sredstva $u$ istu državu. $U$ dijelu o islamskim dobrotvornim a ustvari obavještajno-logističkim društvima, u tekstu je već rečeno o djelovanju istih; o njihovu naoružavanju Armije $\mathrm{BiH}$ i stranih islamističkih terorista i pružanju logističke podrške. Najveći dio njih je osnovala i financirala Saudijska Arabija. Tako je Igassa osnovana 1978.g. u Jeddahu u Saudijskoj Arabiji; ta organizacija je postala glavni kanal za slanje novca, ljudi i oružja mudžahedinima u BiH, sa uredima u Zagrebu, Splitu, Sarajevu i Zenici. Spomenuti BIFMeđunarodna zaklada dobre volje, kao jedna od najmoćnijih islamskih organizacija, je također osnovana od strane bogatog Saudijca Adela Batterjeea, koji je imao i veze s saudijskom kraljevskom obitelji i vladom. Najveće dobrotvorno društvo u Saudijskoj Arabiji je Al Haramain

Saudijci (njihove elite i kraljevska obitelj) povezani s ovim pokretom koji se koristi za radikalizaciju i u terorističke svrhe; https://fas.org/sgp/crs/misc/RS21695.pdf

123 Al Nusra je sunitska ekstremistička islamistička grupa bazirana u Siriji, te je u biti teroristička organizacija nastala iz Al Qai'dine organizacije u Iraku; dio ih je postao Al Nusra te se zakleo na vjernost novom emiru Al Qai'de, Aymanu Zawahiriju, a dio in je pod vodstvom Abu Bakra Al-Baghdadija, postao zloglasni ISIL (Islamska Država); https://www.wilsoncenter.org/article/the-nusrafront-al-qaedas-affiliate-syria

124 https://www.academia.edu/21163179/Iran in the Balkans https://www.tportal.hr/vijesti/clanak/bih-protjerala-dvojicuiranskih-diplomata-20130515/print 
Islamic Foundation sa sjedištem u Rijadu; uredi u Zagrebu i Sarajevu su otvoreni 1992.g. i 1994.g. Ono je osiguravalo logističku potporu ali i vjersku i vojnu izobrazbu mudžahedinima tijekom rata te je uspostavilo veze sa egipatskom terorističkom skupinom Gama'at Al Islamiyya. Ipak, najvažnija organizacija je bila Visoki saudijski komitet za pomoć Bosni i Hercegovini, koju je osnovala direktno država Saudijska Arabija i njen kralj s kojom su unijeli preko 600 milijuna USD u Bosnu i Hercegovinu, većinom za financiranje mudžahedina ali i terorista; nakon 11.rujna snage NATO-a su u uredima ove organizacije našli materijale za terorističke napade i špijunažu. 125

Nakon rata, Saudijci su nastavili širiti svoj utjecaj i ideologiju, većinom ideologiju vehabizma kao tradicionalno snažne islamske fundamentalističke orijentacije $u$ toj državi. Vehabizam ostaje realna opasnost budući da se isti ne libe ni nasilja, dakle islamskog terorizma u ostvarivanju svog cilja. Prosječno, oko 4000 ljudi se skuplja jednom tjedno u džamiji kralja Fahda u Sarajevu koju je financirao osobno saudijski kralj sa 30 milijuna USD. Vehabizam je paralelna struja nasuprot službenoj islamskoj zajednici u Bosni i Hercegovini, i njihove skupine i dalje financiraju Saudijci, kao što i određene mlade muslimane iz Bosne i Hercegovine obrazuju u Saudijskoj Arabiji te šalju svoje operativce u BiH koji se lako stope u bošnjačko društvo.126

Saudijska Kraljevina zadržava ideološko-radikalni pristup u svojoj pomoći muslimanima u Bosni i Hercegovini i bošnjačkim političarima; u samom ratu, Saudijci su potrošili par milijuna eura za " islamsku stvar " u BiH, od mobiliziranja islamističkih boraca do operacija ilegalne trgovine oružjem. Međutim, velika pomoć je došla i u financiranju izgradnje i rekonstrukcije džamije i medrasa (islamskih škola)- sa ciljem širenja vezabizma, s kojim Saudijci imaju povijesne veze.127

125 Mlivončić, Ivica. Al Qaida se kalila u Bosni i Hercegovini, str. 226238; Lučić, Ivo. " Bosna and Herzegovina and Terrorism ", str. 121, 127 passim.

126 Lebl, Leslie. Islamism and Security in Bosnia-Herzegovina, str. 12-15

127 U 18.st., Muhammad Ibn Abd-Al-Wahhab, radikalni konzervativni musliman s Arapskog Poluotoka, je započeo posebnu sektu i vjerski pokret unutar islama nazvan po njemu vehabizam. Ne ulazeći u doktrinarne postavke, dovoljno je reći kako je Wahhab našao sjajnog saveznika u obitelji Saud koja je baš tada preuzela vlast u Arabiji. Vehabizam ostaje službena sekta Kraljevine

Saudijske

Arabije; 
Sa spomenutim saudijskim humanitarnim radom ali $\mathrm{i}$ financiranjem terorista, škola i raznih objekata, izgrađena je paralelna mreža vehabijske zajednice koja se smatra jednim od razloga širenja konzervativne forme islama na Balkanu, a ta je činjenica opet jedan od razloga odlaska oko 800-900 boraca s tog područja u redove ISIL-a. Kosovo i BiH su dvije zemlje koje su, po glavi stanovnika, doprinijele s najviše boraca. 128

Republika Turska je zemlja koja je pomagala i nastavlja pomagati Muslimane u Bosni i Hercegovini, kao i jačanje samog islama kao religije i ideologije. Ona ima možda i najjače poveznice sa Muslimanima u $\mathrm{BiH}$, budući da je islam od Turaka Osmanlija i potekao u Bosni. Kratko rečeno, kraljevinu Bosnu je 1463.g. pokorio sultan Osmanlijskog Carstva Mehmed II. Kao krajna pokrajina svog Carstva, Turci su u njoj naseljavali muslimane i vršili preobraćenja na islam lokalnog stanovništva u Bosni i Hercegovini. Tijekom pada iste države tijekom 19.st., pojavili su se novi igrači; Rusija, Habsburško Carstvo, kao i novonastale balkanske države Srbija, Grčka, Rumunjska, Bugarska koje su se borile, pobijedile i protjerale Turke i dobar dio ostalih muslimana na Balkanu (često in i ubijajući). Ipak, u Bosni i Hercegovini je ostao značajan broj Muslimana, s time da ih danas ima oko $50 \%$ cijelog stanovništva $\mathrm{BiH} .129$

Nakon raspada Jugoslavije, većinom sekularni Muslimani su obnovili svoje povijesne veze sa Turskom preko svojih političkih, vjerskih i akademskih krugova sa ciljem izgradnje etnoreligijskog identiteta Bošnjaka, koji bi bio različit od Hrvata i Srba. Većinom se djelovanje Turske osjeća, sada i prije, preko koncepta "meke moći" (soft power)130 što bi podrazumijevalo ulaganje značajnih financijskih sredstava preko kulturnih udruga i diplomatskih veza, sa ciljem vezivanja Muslimana u Bosni i Hercegovini uz Tursku i time

http://www.europarl.europa.eu/RegData/etudes/ATAG/2017/614582/ 128 EPRS ATA(2017)614582 EN.pdf

http://www.europarl.europa.eu/RegData/etudes/ATAG/2017/614582/ EPRS ATA(2017)614582 EN.pdf

129 Piqueres, Sofia Lopez. Turkey in Bosna and Herzegovina: by fits and starts. Warszava: College of Europe, Department of European Interdisciplinary Studies, 2014, str. 4, 9-11

130 Soft power bi bila sposobnost, moć neke države da ostvari svoje ciljeve u drugim državama bez uporabe sile ili prisile; većinom se odnosi na financijska, kulturna, obrazovna i diplomatska djelovanja; https://www.foreignaffairs.com/reviews/capsule-review/2004-05$\underline{01 / \text { soft-power-means-success-world-politics }}$ 
širenje utjecaja iste na Balkanu. Turska Agencija za Suradnju i Koordinaciju TIKA je pružala financijsku pomoć islamu i muslimanima u $\mathrm{BiH}$ još od rata, a posebno se aktivirala od 2002. g. To je vladina agencija, jedno vrijeme odgovorna izravno turskom premijeru. Nakon što je vladajući AKP preuzeo vlast spomenute godine, aktivnost u Bosni i Hercegovini se pojačala. Samo u 2012.godini ova organizacija je uložila oko 16 milijuna eura u $\mathrm{BiH}, \mathrm{s}$ time da je većina otišla na obnavljanje arhitekture iz otomanskog vremena. Zatim je otvoren Turski kulturni centar u Bosni i Hercegovini u sklopu turskog Veleposlanstva. Također, nakon što je predsjednik i neosporni vladar Turske Recep Erdogan ustanovio fondaciju Yunuse Emre, ista je osnovala i Yunus Emre Institut - Turski kulturni centar u Sarajevu koji je otvorio osobno ministar vanjskih poslova Mehmet Davutoglu. Sve to pokazuje značajan interes Turske i novog "sultana" Erdogana za Bosnu i Hercegovinu.131

Postoje i dva značajna obrazovna centra s kojima Turska širi svoj utjecaj na BiH a time i na Balkanu. Prvi je Internacionalni Univerzitet u Sarajevu, kojeg je osnovao turski poslovni čovjek s dobrim vezama sa Erdoganom. Ono pohađa oko tisuću i pol studenata, predavanja se vrše na engleskom jeziku $\mathrm{i}$ služi razmjeni turskih $\mathrm{i}$ bosanskih, ali $\mathrm{i}$ drugih studenata. Drugi je Međunarodni Univerzite Burch koji ima veze sa Fethullahom Gullenom, turskim vjerskim autoritetom i čovjekom koji vodi cijelu međunarodnu obrazovnu mrežu iz SAD-a (Pennsylvania).132

\section{Zaključak - moguće mjere Republike Hrvatske protiv islamistočkog terorizma}

Republika Hrvatska je srednjeuropska, podunavska, mediteranska ali i zemlja na jugoistoku Europe. S površinom od $56538 \mathrm{~km}^{2}$ i oko 4 milijuna stanovnika, spada u manje zemlje Europske Unije. RH je demokratska država $\mathrm{s}$ parlamentarnim sustavom; taj parlament je Sabor a ujedno je i nostielj zakonodavne vlasti, dok je premijer predsjednik vlade $\mathrm{RH}$. Predsjednik $\mathrm{RH}$, kao i Sabor, sudjeluju u

131 Mujadižević, Dino. " Turkey's Role in Bosna and Herzegovina ", Euxenios- Governance and Culture in the Black Sea Region, 23, str. 25- 29

132 https://www.theguardian.com/world/2013/apr/02/bosnia-turkeyottoman-influence-balkans-sarajevo 
upravljanju sustavom nacionalne sigurnosti.133 Njen temeljni zakon je Ustav RH.134 Obavještajne službe RH su prešle dug put od 1991. pa do reorganizacije i novog Zakona o sigurnosno-obavještajnom sustavu Republike Hrvatske, donesenog 2006.135 Tijekom 90-ih godina, postojalo je par sigurnosnih i obavještajnih službi kao što su bile UNS - Ured za nacionalnu sigurnost, čija je zadaća bila koordinacija svih hrvatskih obavještajnih službi, a unutar UNS-a je spadao i HIS - Hrvatska izvještajna služba kao vanjska civilna obavještajna služba. SZUP - Služba za zaštitu ustavnog poretka je bila ustrojena u okviru Ministarstva unutarnjih poslova, SIS Sigurnosno izvještajna služba je bila vojna sigurnosna služba čija je zadaća bila protuobavještajna zaštita vojnog vrha, vojno-redarstvenih operacija i postrojbi. Reformom iz 2002., napravljena je reorganizacija pa su tako nastale $O A$ Obavještajna agencija i POA - Protuobavještajna agencija, s tim da je za vojno obavještajno djelovanje i protuobavještajni rad u sektoru MORH-a i HV-a bila zadužena VSA - Vojna sigurnosna agencija.136 Kada je donesen spomenuti ZSOS (Zakon o sigurnosno-obavještajnom sustavu) 2006., taj sustav je organiziran da mu okosnicu čine dvije službe: $S O A$ - Sigurnosno-obavještajna agencija i VSOA - Vojna sigurnosno-obavještajna agencija. U sustavu postoji i VNS Vijeće za nacionalnu sigurnost koje djeluje kao središnje političko-savjetodavno tijelo koje ocjenjuje ugroze nacionalne sigurnosti i politiku zaštite iste. Savjet za koordinaciju sig.-ob. agencija operativno usklađuje rad svih službi. Za tehničkokomunikacijska pitanja su zaduženi Zavod za sigurnost informacijskih sustava, kao i Operativno-tehnički centar za nadzor telekomunikacija.137

Republika Hrvatska se nalazi u relativno nepovoljnom geopolitičkom okruženju budući da joj se u neposrednom okruženju nalaze neka krizna žarišta (u prvom redu veoma

133

The

World

Factbook,

CIA;

https://www.cia.gov/library/publications/the-world-

factbook/geos/hr.html

134 Narodne novine 56/90, 135/97

135 Narodne novine 79/06

136 Tatalović, Siniša- Grizold, Anton- Cvrtila, Vlatko. Suvremene sigurnosne politike. Zagreb: Golden marketing- Tehnička knjiga, 2008., str. 318- 20

137 Zakon o sigurnosno-obavještajnom sustavu $\mathrm{RH}$, Narodne novine 79/06; Badžim, Joško. "Sigurnosno-obavještajne službe u demokratskom društvu- u povodu reforme sigurnosnoobavještajnog sustava u Republici Hrvatskoj", Hrvatska javna uprava 8 (4), str. 1018-1019 
podijeljena Bosna i Hercegovina i Kosovo), kao i Republika Srbija koja je bivši agresor na RH i čiji čelnici često nastavljaju velikosrpsku retoriku. Također, cijela jugoistočna Europa (Balkanski poluotok) je područje sigurnosnih rizika. U BiH su dugo djelovale međunarodne mirovne snage, a Balkanski poluotok je također područje gdje je zabilježena veća aktivnost raznih islamističkih skupina koje su dijelom i financirane od arapskih država.138 Kao sredozemna, srednjoeuropska i podunavska zemlja, $\mathrm{RH}$ ima važno geoprometno značenje u razvoju europskih komunikacija, no zbog ratova i područja napetosti, Hrvatska nije u potpunosti iskoristila svoj položaj; uz to, sam oblik države je dovodi u nepovoljan položaj u vojnom i sigurnosnom smislu. Ipak, u europskim integracijskim procesima, ti nedostatci se mogu nadvladati.139

$\mathrm{U} \mathrm{RH}$ u slučaju kriminalnog djela terorizma, $u$ istragu se uključuje državni odvjetnik kao koordinator i on radi sa svim agencijama - policijom, obavještajnom službom. U prevenciji terorističkih akata i otkrivanju pojedinaca i skupina, $\mathrm{RH}$ bi se mogla ugledati na državu $s$ kojom je nedavno ostvarila strateško partnerstvo - Državu Izrael. Izrael ima dugu povijest borbi protiv islamskog terorizma koja praktički seže od samog nastanka Izraela kao samostalne države. Tijekom desetljeća, Izrael je razvio protuterorističku strategiju u kojima glavnu ulogu imaju njihove obavještajne službe: Mosssad (Institut za obavještajni rad i specijalne zadatke)140, Shin Bet (Opća sigurnosna služba)141 te Aman (Vojnoobavještajna služba)142. Ključna organizacija je Aman (Agaf ha-Mod'in), obavještajna služba Izraelskih Oružanih Snaga (IDF - Israeli Defence Forces). U službi u kojoj radi oko sedam tisuća ljudi, prikupljaju se i analiziraju informacije prikupljene pomoću ELINT-a (Electronic Intelligence) i COMINT-a (Communications Intelligence) uz pomoć posebne antiterorističke jedinice Sayeret Mat'kala. Aman dnevno

138 Žunec, Ozren.- Domišljanović, Darko. Obavještajno-sigurnosne službe Republike Hrvatske, str. 188; Gibas- Krzak, Danuta. " Terrorism in the Balkans. Genesis- types- prognoses ", str. 328 i d.

139 Lozančić, Marinko. " Sigurnosni izazovi za Republiku Hrvatsku u euroatlantskom geostrategijskom kontekstu " u: Sigurnost $i$ obrana Republike Hrvatske u euroatlantskom kontekstu (ur. Smerić, Tomislav i Sabol, Gabrijela). Zagreb: Institut društvenih znanosti Ivo Pilar, 2009., str. 41-42, sl.2.

140 www.mossad.gov.il

$141 \mathrm{https}: / /$ www.shabak.gov.il/english/

142 http://www.globalsecurity.org/intell/world/israel/aman.htm 
izvješćuje glavni vojni stožer, ministarstvo obrane, predsjednika vlade i članove vlade o prikupljenim i analiziranim podatcima, te daje godišnju procjenu premijeru i vladi o opasnostima terorizma.143 Prvi i osnovni element na kojem se bazira izraelska protuteroristička strategija je prikupljanje i analiza obavještajnih podataka. Osim razvijenih visokotehnoloških špijunskih uređaja i povremenih racija među Palestincima, velika se pozornost usmjerava prema podacima s terena koje se dobiva putem ubačenih agenata ili vrbovanih Palestinaca. Pokazalo se da je HUMINT (Human Intelligence)144 najpouzdaniji tip obavještajnih podataka.145 Iskustvo potvrđuje da se terorizam ne može učinkovito i trajno suzbiti ako se ne koriste povjerljive obavijesti koje mogu dovesti do predviđanja i anticipiranja prijetnje, neutraliziranja njenih tvoraca i sudskog suzbijanja terorističkog napada. Radi toga ubacivanje ljudskih potencijala među terorističke organizacije mora i dalje biti (uz svu složenost i opasnost takvih akcija) jedan od prioriteta sigurnosnih i obavještajnih službi.146 S time računajući, $\mathrm{RH}$ bi također trebala znati kako se postaviti prema potencijalnim terorističkim islamističkim prijetnjama, pogotovo uzevši u obzir sve bolju suradnju s Državom Izrael147 gdje je i izraelski predsjednik spomenuo Hrvatsku kao " snažnog saveznika u EU, NATO-u i multilatelarnim organizacijama ".148

Islamistički je terorizam, kako je rečeno, postao transnacionalna i transgranična ugroza demokratskom svijetu a njegov glavni ideološki obrazac je vjerski fanatizam koji dovodi i do samoubilačkih terorističkih djelovanja. Ljudski resursi u borbi protiv terorizma se mogu koristiti na više polja,

143 Collona Vilasi, Antonella. " The Israeli Intelligence Community ", Sociology Mind 8, 2018, str. 121; Vidušić, Emil. Vodič kroz tajne službe. Split: Naklada Bošković, 2004., str. 34-36

144 HUMINT se definira kao obavještajna aktivnost s osloncem na ljudske izvore; agente, informatore, doušnike, konfidente, klasične špijune i druge; Vidušić, Emil. Vodič kroz tajne službe. Split: Naklada Bošković, 2004., str. 20

145 Tatalović, Siniša- Grizold, Anton- Cvrtila, Vlatko. Suvremene sigurnosne politike: Države i nacionalna sigurnost početkom 21.stoljeća. Zagreb: Golden marketing- Tehnička knjiga, 2008.,str. 330- 332

146 Gayraud, Jean-Francois.- Senat, David. Terorizam. Zagreb: Jesenski i Turk, 2008., str. 68-69

147 https://vijesti.hrt.hr/540979/ugovor-hrvatske-i-izraela-na-podrucjujavne-sigurnosti

148 https://www.jutarnji.hr/vijesti/hrvatska/izraelski-predsjednik-ujeruzalemu-primio-grabar-kitarovic-hvala-vam-sto-se-suprotstavljatemrznji-prema-izraelu/9177821/ 
ali u dva glavna smjera a to su prevencija terorizma i operativna borba protiv istog. Naime, preventivno djelovanje dugoročno ide u smjeru edukacije, ublažavanju fanatizma od odgoja pojedinca i sprječavanje indoktrinacije - za taj je proces potrebna suradnja psihologa, sociologa ali i vjerskih autoriteta. Prevencija terorističkih akata terorističkih organizacija ide u smjeru pravodobnog i preciznog obavještajnog rada - procesa koji je apsolutno nužan jer se obavještajnim radom mogu otkriti materijalne, financijske i infrastrukturne značajke terorističkih skupina, a onda ih se i ublažiti i sprječiti. Operativna borba je već gašenje požara - s time se bave visoko uvježbane i specijalizirane vojne i policijske snage.149

Uloga RH može i mora biti u stabiliziranju odnosa u jugoistočnoj Europi i efektivnoj antiterorističkoj borbi koja se mora ostvarivati temeljena na znanju - to podrazumijeva poboljšanje razmjena obavještajnih informacija kao i stvaranje zajedničkih baza podataka o terorističkim organizacijama i njihovim članovima. Na koncu, eliminiranje svakog, pa i islamističkog terorizma uspijeva jedino ako se eliminiraju socijalni uvjeti koji su doveli do istog te ako se uspostavi pravodobna razmjena informacija na nacionalnoj, regionalnoj i globalnoj razini.150 Tu pogotovo dolazi u obzir strateško partnerstvo i dobra suradnja s Državom Izrael koja ima posebno razrađene antiterorističke strategije.

Republika Hrvatska je u svojoj Strategiji nacionalne sigurnosti donesenoj 2017.g.151 definirala sigurnost i teritorijalni integritet i cjelovitost kao jednu od temeljnih sastavnica nacionalnih interesa i posvetila dio istog dokumenta o terorizmu kojeg imenuje stalnom nacionalnom i međunarodnom prijetnjom za područje Europe, pogotovo iz teritorija sjeverne Afrike, Bliskog Istoka i Kavkaza. Također je naglašeno kako su se tisuće Europljana pridružile terorističkim skupinama u Iraku i Siriji (posebice ISIL-u) i po povratku predstavljaju dugoročni rizik.

149 Matika, Dario Ogorec, Marinko. " Ljudski resursi u borbi protiv terorizma " u: Ljudski resursi u suzbijanju terorizma (ur.Antoliš, Krunoslav). Zagreb: Znanstveno-stručni skup 7.-8.rujna 2006., 2007., str. 55-59

150 Knezović, Sandro. " Ljudski resursi u suzbijanju terorizmapotencijalna uloga $\mathrm{RH}$ " u: Ljudski resursi u suzbijanju terorizma (ur.Antoliš, Krunoslav). Zagreb: Znanstveno-stručni skup 7.8.rujna 2006., 2007., str. 96-99

151 Narodne novine $73 / 2017$ 
Nacionalna strategija za prevenciju terorizma, dokument donesen 2015.g. od Vlade $\mathrm{RH}_{152}$ definira borbu protiv terorizma kroz prevenciju i suzbijanje i ponovno ističe područje jugoistočne Europe kao dio prema kojem se $\mathrm{RH}$ mora okrenuti na dva načina; kroz suradnju policijskih i obavještajnih institucija $s$ drugim državama te kroz stabilizaciju regije, sprječavajući tako krizne situacije na Balkanu i izbjegavajući moguću radikalizaciju, pogotovo mladih ljudi.

Prema sadašnjem Zakonu o sigurnosno-obavještajnom sustavu $\mathrm{RH} 153$, sigurnosno-obavještajne agencije SOA i VSOA imaju obvezu i mogućnost raznih djelovanja protiv terorizma. Objema agencijama je definirano prikupljanje i daljna obrada podataka (za vojnu službu stoji da prikuplja podatke na teritoriju $\mathrm{RH}$ ), kao i suradnja s drugim obavještajnim agencijama. Vrlo je bitno da je člankom 29. određeno kako obavještajne agencije mogu koristiti tajne suradnike, što je značajno kada se usporedi sa iskustvom Izraela154 u vrijednosti HUMINT-a.155 Također se člankom 33.određuje i mogućnost mjera tajnog prikupljanja podataka raznima sredstvima i metodama. Člankom 59. se i zakonski određuje moguća suradnja s stranim obavještajnim i sigurnosnim službama u vidu razmjene podataka i ostalih poslova. Tako je legalno utvrđena mogućnost suradnje i razmjene podataka i edukacije djelatnika među sigurnosnim i obavještajnim službama - ključne sastavnice u suzbijanju terorističkih islamističkih skupina.

Što se tiče mogućnosti iskorištavanja ljudskih izvora u prikupljanju obavještajnih podataka vezanih uz opasnost islamističkog terorizma, $\mathrm{RH}$ i njene institucije trebaju imati na umu da se među potencijalnim ad hoc ljudskim izvorima

152 Narodne novine $108 / 15$

153 Narodne novine 79/06

154 No ne samo Izraela; jedna od najuspješnijih i profesionalnijih obavještajnih službi u suzbijanju islamističkog terorizma jest jordanski GID ( eng. General Intelligence Directorate ) koja je samo jedne godine sprječila preko 90 aktivnosti terorista; http://www.jordantimes.com/opinion/fares-braizat/unknown-knightscountering-terrorism-conviction

155 Jedan od najboljih primjera o vrijednosti ljudskih izvora obavještajnih podataka u suzbijanju terorizma jest slučaj Palestinca Mosaba Hassana Yousefa, sina jednog od vođa Hamasa na Zapadnoj obali, koji je godinama radio za izraelski Shin Bet ( Shabak ) te je svojim djelovanjem sprječio na desetke napada, terorističkih čina i atentata na izraelske dužnosnike; https://www.haaretz.com/1.5051790 
nalaze ratne i političke izbjeglice, prebjezi i azilanti i određeni stručnjaci iz područja koji mogu biti relevantni za obavještajnu službu. S pojavom islamskog terorizma i njihovih ćelija, značaj ljudskih izvora je porastao; terorističke organizacije se same služe tehničkim sredstvima, imaju i protuobavještajnu komponentu a ključne i vitalne informacije se prenose na neposredan način između zatvorenog kruga ljudi. $U$ takvoj situaciji važnost HUMINT-a ili ljudskih izvora je teško opisiva.156

\section{Bibliografija}

1. Akrap, Gordan. "Mač i štit u rukama Partije- represivni sustav u funkciji oblikovanja javnog znanja", National Security and the Future 4 (11), 2011

2. Anderson, Sean K.- Sloan, Stephen. Historical Dictionary of Terrorism. Lanham - Toronto - Plymouth: The Scarecrow Press, 2009.

3. Avramov, Kiril. "Under the Radar: Iran's Stealth Presence on the Balkans ", The Globe Post 2018.

4. Badžim, Joško. Obavještajna državna tijela i kriminalitet. Split: Web Knjižara, 2014.

5. Badžim, Joško. "Sigurnosno-obavještajne službe u demokratskom društvu- u povodu reforme sigurnosnoobavještajnog sustava u Republici Hrvatskoj", Hrvatska javna uprava 8 (4).

6. Bilandžić, Mirko. "Al-Qaida: nastanak, struktura i strategija", Polemos 11 (1).

7. Bilandžić, Mirko. "Islamske oružane organizacije i islamizam na primjeru Bliskog istoka ", Revija za sociologiju, XXXIX (4).

8. Bilandžić, Mirko. Sjeme zla: Uvod u studije terorizma. Zagreb: Despot Infinitus, 2014.

9. Central Intelligence Agency ( 1995 ). Intelligence Report. $\mathrm{DCl}$ Counterterrorist Center. Preuzeto s: https://www.cia.gov/library/readingroom/docs/1995-1122A.pdf. 
10. Collona Vilasi, Antonella. "The Israeli Intelligence Community ", Sociology Mind 8.

11. Fisher, Sydney Nettleton. "The Egyptian Republic and Independent Sudan" u: Ochsenwald, William - Fisher, Sydney. The Middle East: A History. New York: McGraw-Hill, 2004.

12. Fisher, Sydney Nettleton. "The Islamic Republic of Iran, the Collapse of the Soviet Union, and War in Afghanistan" u: Ochsenwald, William-Fisher, Sydney. The Middle East: A History. New York: McGraw-Hill, 2004.

13. Gayraud, Jean-Francois - Senat, David. Terorizam. Zagreb: Jesenski i Turk, 2008.

14. Gibas- Krzak, Danuta. "Terrorism in the Balkans. Genesis - types - prognoses", Internal Security Review 19/18.

15. Gunaratna, Rohan- Oreg, Aviv. "Al Qaeda's Organizational Structure and its Evolution", Studies in Conflict and Terrorism 33 (12)

16. Hide, Enri. "Islamic Extremism in the Balkans as a Geopolitical Instrument", Mediterranean Journal of Social Sciences 5 (6), 2014.

17. http://www.dia.mil/

18. http://www.enciklopedija.hr/natuknica. aspx?id=28280

19.http://www.europarl.europa.eu/RegData/etudes/ATAG/20 17/614582/EPRS_ATA(2017)614582_EN.pdf

20. http://www.globalsecurity.org/intell/world/israel/aman.htm

21. http://www.iranicaonline.org/articles/guardian-council

22.http://www.jordantimes.com/opinion/faresbraizat/unknown-knights-countering-terrorism-conviction

23. https://2009-2017.state.gov/j/ct/rls/crt/2014/239410.htm

24. https://fas.org/irp/world/iran/mois-loc.pdf

25. https://fas.org/sgp/crs/misc/RS21695.pdf

26. https://ourworldindata.org/terrorism

27. https://vijesti.hrt.hr/540979/ugovor-hrvatske-i-izraela-napodrucju-javne-sigurnosti

28.https://www.academia.edu/21163179//ran_in_the_Balkan $\mathrm{s}$ 
29.https://www.academia.edu/21163179/Iran_in_the_Balkan $\mathrm{s}$

30.https://www.academia.edu/21163179/Iran_in_the_Balkan s;https://www.tportal.hr/vijesti/clanak/bih-protjerala-dvojicuiranskih-diplomata-20130515/print

31.https://www.aljazeera.com/news/2019/04/designatesiran-elite-irgc-terrorist-organisation-trump190408141756166.html

32.https://www.balkanspost.com/article/583/potentialterrorism-balkans-part-5-us-government-accusationspogorelica-cas

33.https://www.euronews.com/2019/12/19/islamic-statefighters-and-their-families-return-to-bosnia

34.https://www.foreignaffairs.com/reviews/capsulereview/2004-05-01/soft-power-means-success-world-politics 35.https://www.globalsecurity.org/intell/world/iran/jcso.htm 36.https://www.globalsecurity.org/intell/world/iran/vevak.htm 37.https://www.globalsecurity.org/intell/world/iran/vevak.htm 38.https://www.haaretz.com/1.5051790

39.https://www.jpost.com/International/Report-warns-ofHezbollah-Iran-threats-in-Balkans-309596

40.https://www.jutarnji.hr/vijesti/hrvatska/izraelskipredsjednik-u-jeruzalemu-primio-grabar-kitarovic-hvala-vamsto-se-suprotstavljate-mrznji-prema-izraelu/9177821

41.https://www.nytimes.com/2006/02/18/us/national-briefingmidwest-illinois-new-sentence-for-charity-director.html

42.https://www.nytimes.com/2019/04/30/world/middleeast/isthe-muslim-brotherhood-terrorist.html

43.https://www.reuters.com/article/us-bosnia-usaembassy/gunman-attacks-u-s-embassy-in-bosniaidUSTRE79R66F20111028

44.https://www.shabak.gov.il/english/

45.https://www.theguardian.com/world/2013/apr/02/bosniaturkey-ottoman-influence-balkans-sarajevo

46.https://www.theguardian.com/world/2017/oct/03/morethan-20-percent-countries-have-official-state-religions-pewsurvey Pristup 23.5.2019., 23.5.2019. 
47.https://www.theguardian.com/world/2017/oct/03/morethan-20-percent-countries-have-official-state-religions-pewsurvey, 23.5.2019.

48.https://www.un.org/securitycouncil/sanctions/1267/aq_sa nctions_list/summaries/entity/benevolence-internationalfoundation

49.https://www.wilsoncenter.org/article/the-nusra-front-alqaedas-affiliate-syria

50. Kissinger, Henry. Svjetski poredak. Zagreb: Školska knjiga, 2015.

51. Knezović, Sandro. "Ljudski resursi u suzbijanju terorizmapotencijalna uloga $\mathrm{RH}^{\prime \prime}$ u: Ljudski resursi u suzbijanju terorizma (ur. Antoliš, Krunoslav). Zagreb: Znanstvenostručni skup 7.-8.rujna 2006., 2007.

52. Kohlmann, Evan. Al-Qa'idin džihad u Europi: Afganistansko-bosanska mreža. Zagreb: Naklada Ljevak, 2005.

53. Kulenović, Tarik. Politički islam: Osnovni pojmovi, autori $i$ skupine jednog modernog političkog pokreta. Zagreb: V.B.Z., 2008.

54. Lebl, Leslie. Islamism and Security in BosniaHerzegovina. Carlisle, PA: Strategic Studies Institute and U.S. Army War College Press, 2014.

55. Lozančić, Marinko. "Sigurnosni izazovi za Republiku Hrvatsku u euroatlantskom geostrategijskom kontekstu" u: Sigurnost i obrana Republike Hrvatske u euroatlantskom kontekstu (ur. Tomislav Smerić, Gabrijela Sabol). Zagreb: Institut društvenih znanosti Ivo Pilar, 2009.

56. Lučić, Ivica. Uzroci rata: Bosna i Hercegovina od 1980. do 1992.godine. Zagreb: Despot Infinitus, 2013.

57. Lučić, Ivo. "Bosna and Herzegovina and Terrorism", National Security and the Future 3-4 (2), 2001.

58. Mantran, Robert. "Muhamed i islam" u: Povijest 5 - Kasno Rimsko Carstvo i rani srednji vijek (ur. Enrico Cravetto). Zagreb: Jutarnji list, 2007.

59. Matika, Dario - Ogorec, Marinko. "Ljudski resursi u borbi protiv terorizma" u: Ljudski resursi u suzbijanju terorizma (ur. Antoliš, Krunoslav). Zagreb: Znanstveno-stručni skup 7.-8. rujna 2006., 2007. 
60. Mlivončić, Ivica. Al Qaida se kalila u Bosni i Hercegovini. Split - Mostar: Naša ognjišta - Tomislavgrad, 2007.

61. Mozaffari, Mehdi. "What is Islamism? History and Definition of a Concept", Totalitarian Movements and Political Religions, 8 (1).

62. Mujadižević, Dino. "Turkey's Role in Bosna and Herzegovina", Euxenios - Governance and Culture in the Black Sea Region, 23.

63. Narodne novine $108 / 15$

64. Narodne novine 56/90, 135/97

65. Narodne novine $73 / 2017$

66. Narodne novine $79 / 06$

67. Narodne novine $79 / 06$

68. NATO Leksikon (ur. Aleksandar Laković, Kristina Stojan). Zagreb: Topical, 2008

69. Ochsenwald, William. "Muhammad: His Life and Lidership" u: Ochsenwald, William-Fisher, Sydney. The Middle East: A History. New York: McGraw-Hill, 2004.

70. Piqueres, Sofia Lopez. Turkey in Bosna and Herzegovina: by fits and starts. Warszava: College of Europe, Department of European Interdisciplinary Studies, 2014.

71. Starešina, Višnja. Hrvati pod KOS-ovim krilom. Zagreb: Avid Media - Hrvatsko katoličko sveučilište, 2017.

72. Tatalović, Siniša - Grizold, Anton - Cvrtila, Vlatko. Suvremene sigurnosne politike. Zagreb: Golden marketing Tehnička knjiga, 2008.

73. The World Factbook, CIA; https://www.cia.gov/library/publications/the-worldfactbook/geos/hr.html.

74. Tuđman, Miroslav. Druga strana Rubikona: Politička strategija Alije Izetbegovića. Zagreb: Hrvatska sveučilišna naklada, 2017.

75. Venner, Dominique. Povijest terorizma. Zagreb: Alfa, 2005.

76. Vidušić, Emil. Vodič kroz tajne službe. Split: Naklada Bošković, 2004.

77. Vukadinović, Radovan. Politika i diplomacija. Zagreb: Otvoreno Sveučilište, 1984. 
78. Wege, Carl Anthony. "Iran's Intelligence Establishment", The Intelligencer: Journal of U.S. Intelligence Studies, 21 (2). 79. www.mossad.gov.il.

80. Zakon o sigurnosno-obavještajnom sustavu RH, Narodne novine 79/06.

81. Žunec, Ozren - Domišljanović, Darko. Obavještajnosigurnosne službe Republike Hrvatske. Zagreb: Jesenski i Turk, 2000. 